\title{
LA CONSTRUCCIÓN DE LA IDENTIDAD A TRAVÉS DEL TERRITORIO EN LA EDAD MEDIA. EL ORIGEN BEREBER DEL NOMBRE DE MADRID
}

\author{
EDUARDO JIMÉNEZ RAYADO ${ }^{1}$ \\ Universidad Rey Juan Carlos
}

Recibido: 20 de octubre de 2019

Aceptado: 05 de mayo de 2020

\begin{abstract}
Resumen
Sin entender el territorio, nuestro conocimiento del pasado constituye un paisaje incompleto. La tierra ha sido, es y será esencial en la vida del ser humano. Este trabajo pretende ayudar a completar ese paisaje analizando el papel que tuvo el territorio en dos momentos clave en el proceso de construcción de las identidades colectivas: la formación de los topónimos y la creación de una imagen de honra y orgullo, en este caso, durante la Edad Media. De todos los elementos del territorio que sirvieron para ambos casos, el agua adquirió un especial protagonismo. Madrid, objeto de análisis que cerrará este trabajo, es uno de los ejemplos más claros de ese papel del agua en la construcción de una identidad.
\end{abstract}

\section{Palabras clave}

Identidad, territorio, agua, toponimia, Historia urbana, Edad Media.

\begin{abstract}
Our knowledge of human past remains incomplete without an understanding of the territory. Land has always been essential for human life. This article aims at broadening this knowledge by analyzing the role of territory in the construction of collective identity at two key moments: in the creation of toponyms and in the building up of an image of pride and reputation, in this case, during the Middle Ages. Among all the territorial elements present in both processes, water had a special prominence. Madrid, the closing chapter of this piece of research, is one of the most clear examples of the importance of water in identity development.
\end{abstract}

\section{Keywords}

Identity, territory, water, Toponyms, Urban History, Middle Ages.

1 Grupo de investigación ITEM (Identidad y Territorio en la Edad Media). Universidad Rey Juan Carlos. Correo electrónico: eduardo.jimenez@urjc.es. ORCID: https://orcid.org/0000-0002-9611-1260. 


\section{Riassunto}

Il nostro conoscimento del pasato rimane incompleto senza interpretare il territorio. La terra è stata esenziale nella vita del essere umano. Questo lavoro tenterà d'auitare a completare quel conoscimento analizzando il ruolo che ebbe il territorio nel processo di costruzione delle identità colective in due momenti chiave: la formazione dei toponimi e la creazione di un'immagine d'onore e d'orgoglio durante il Medioevo. Tra tutti gli elementi del territorio presenti nei due processi, l'acqua ebbe una ribalta speciale. Madrid, oggeto d'annalisi nell'ultima parte di questo articolo, è uno dei esempi più chiari de quel ruolo dell'acqua nella costruzione dell'identità.

\section{Parole chiave}

Identità, territorio, acqua, toponimia, Storia urbana, Medioevo

\section{Introducción}

El territorio, ese espacio que nos rodea y sobre el que nos asentamos, muchas veces olvidado y obviado en los análisis de nuestro pasado, ha influido, influye e influirá en la formación de una población. El ser humano, y de eso ahora somos más conscientes que nunca, ha transformado gran parte del paisaje. Pero la influencia es recíproca. La tierra ha determinado la forma que tendrá un asentamiento humano, ha sido determinante en su organización espacial, en su economía, en la manera de comprender y actuar en un espacio y, en definitiva, la manera de entender nuestra propia vida. No se llega a comprender por qué las formas de vida y el pasado de una localidad escandinava es tan diferente a la de un pequeño pueblo andaluz si no se tiene en cuenta el territorio donde cada uno de ellos está asentado. La tierra, en fin, da forma a nuestra identidad. Desde el momento en que gran parte de la humanidad se fue haciendo sedentaria, allá por el Neolítico, esta comenzó a identificarse con el territorio que ocupaba y comenzó a creerse que le pertenecía. Y los seres humanos y la tierra se hicieron uno. ¿Son aquellas construcciones milenarias que conocemos como megalíticos prueba de aquella primitiva identificación?

Este trabajo no es tan ambicioso como para responder a esta pregunta. Su objetivo es buscar entre la espinosa cuestión de la identidad para encontrar y comprender qué papel tuvo o tiene el territorio en la configuración del sentimiento identitario colectivo de una población. No pretende arrancar desde los inicios del sedentarismo humano. El marco cronológico del presente trabajo se encuentra en un periódico histórico concreto: la Edad Media. En esos siglos, el fenómeno urbano recuperó su vigor en el territorio cristiano ibérico a partir del siglo XI. Entonces, las diferentes ciudades de aquella parte de la Península comenzaron a fraguarse una imagen que proyectar tanto hacia el exterior como hacia su interior; una imagen con la que identificarse.

Pasado, fuerza, belleza: fueron muchos los elementos utilizados para forjar su imagen. En este trabajo me centraré en uno de ellos: el nombre. Porque es el topónimo, el nombre de un lugar, uno de los primeros elementos con que la población se identifica colectivamente. Conscientes de ello, infinidad de textos, a lo largo de los siglos, han 
tratado de explicar el significado y el origen de esos topónimos, bien propios, bien ajenos. En muchos casos, su objetivo real no era otro que dar prestigio al lugar, y por ello se buscaron respuestas de lo más inverosímiles, fantasiosas y legendarias.

En la formación de muchos de esos nombres, el territorio y sus características tuvieron un papel protagonista. Por ello resulta imprescindible para este trabajo echar mano de la toponimia, del "estudio de los nombres de lugares, es decir de nombres atribuidos por el individuo (significantes) a realidades geográficas (significados)"2 en palabras del historiador francés Robert Delort.

Tras un repaso por el papel del territorio en el proceso de formación de nombres e identidades de las ciudades y localidades, me centraré en el caso de Madrid. La razón, lógicamente, no tiene que ver con cualquier tipo de afinidad o vínculo con la ciudad o por el hecho de haber sido centro de la mayor parte de mis investigaciones. Más bien, su ejemplo vendrá dado porque refleja muy claramente el objetivo de este trabajo. A falta de grandes héroes/heroínas, de grandes batallas a su alrededor o de un pasado glorioso, y ante las limitadas dimensiones de su recinto, Madrid se fijó en su territorio para construirse una identidad propia que le distinguiera del resto y con la que su población se sintiese vinculada. Esta relación territorio/identidad comenzó en los propios orígenes de la ciudad, en tiempos bereberes, y se vio reforzada a partir de los siglos XIII y XIV, ya como Villa castellana. En ella, tuvo un protagonismo esencial un elemento concreto de ese territorio: el agua, que dio a Madrid un elemento de orgullo $\mathrm{y}$, sobre todo, un nombre. Por ello, la última parte del presente artículo se adentrará en los orígenes de la ciudad en busca de las raíces de su nombre, hará un pequeño repaso por las diferentes teorías sobre su significado, estudiará el territorio donde se asentó, para concluir con una nueva propuesta sobre qué encierra aquel nombre que impuso la primera comunidad bereber y que hoy identifica a la capital de España.

\section{Identidad/es}

Los seres humanos necesitamos una identidad. Como seres sociales que somos, tenemos la necesidad de sentirnos parte de algo. Ese sentimiento nos ayuda a dar cierto sentido a nuestra existencia, como individuos y como comunidad. Nos salvaguarda, en fin, de ese miedo visceral tan nuestro a sentirnos solos en el universo. Ser parte de algo mitiga ese miedo y nos da algunas respuestas al enigma de por qué estamos aquí. En definitiva, la identidad "es uno de esos conceptos básicos en torno a los cuales los individuos y las sociedades pretenden construir su existencia"s.

Quizá debería usar el plural: identidades, porque son varias las que usamos para realizar la construcción de nuestro ser. Identidades que nos llevan a sentirnos parte de comunidades o grupos muy diferentes entre sí, dependiendo del elemento o factor a partir de

\footnotetext{
2 Delort, Introduction aux sciences auxiliaires de l'histoire, p. 184; cit. Mazzoli-Guintard, Madrid. Pequeña ciudad de al-Andalus, p. 44.

3 Ruiz Gómez, "La ilusión de la identidad en el imaginario medieval según Las Partidas", p. 241.
} 
la cual construimos esa identidad. El territorio, la ideología política, el momento del nacimiento, el ámbito laboral, incluso el horóscopo son diferentes mecanismos que nos hacen sentir esa pertenencia a distintos colectivos. El individuo puede sentirse vinculado a otro por compartir un territorio, pero al mismo tiempo ver en este una imagen de alteridad, al verdadero 'otro', opuesto a él a partir de otros parámetros identitarios, como por ejemplo la ideología política. Para evitar el caos que supondría ese mosaico identitario, el individuo o la comunidad teje un hilo conductor entre todas ellas a partir del cual construir una identidad general con la que sentirse reconocido/a.

Pero, ¿cómo se construyen esas identidades? El ser humano ha estado y está rodeado de elementos y factores que pueden ser la base de aquellas. Localizar esas identidades, comprenderlas y explicar sus raíces no es tarea sencilla. Buscarlas es, en términos de Zygmunt Bauman, intentar "cuadrar un círculo"4. Y si resulta dificultoso para la actualidad, ¡cuánto más resulta hacerlos para tiempos pretéritos! ¿Cuándo surge? ¿En qué momento se puede considerar una identidad bien definida y aceptada, siendo conscientes que su formación es un proceso constante?s.

Son centenares las obras que, desde la sociología principalmente, han ido apareciendo para desentrañar qué es, cómo surge y cómo funciona una identidad/identidades. Esta tendencia parece resurgir en aquellos momentos en los que se generaliza una crisis identitaria, como podría ser el fenómeno de la globalización. A partir de entonces han sido numerosas las teorías que han ido desembocando en enfrascados debates donde más que respuestas, el lector o lectora encontrará un amplio abanico de ideas, interpretaciones y conceptos muy diversos.

Este pequeño estudio parte de la idea de que el ser humano utiliza diferentes elementos para construir un sentimiento de colectividad. Elementos que están, de una manera u otra, presentes en su vida cotidiana. En un principio se podría pensar que este proceso de selección de dichos elementos es voluntario y así lo han defendido varios autores:

"Es posible afirmar, por lo tanto, que la identidad es un acto voluntariamente aceptado por la imaginación de los individuos. Queremos ser de una forma porque, previamente, hemos construido un modelo con el que nos identificamos voluntariamente. Esto que afirmamos para el presente, podría ser aplicado también al hombre medieval, aunque sus deseos se expresaran con otros lenguajes".

Sin embargo, creo que en cierto modo existe un punto de involuntariedad. Efectivamente el ser humano busca algo con lo que construir una identidad y, por tanto, es un acto voluntario. E incluso puede llegar a elegir qué elementos podrían llegar a construirla. Pero eso no significa que se conviertan automáticamente en identitarios. Es entonces

\footnotetext{
Bauman, Identidad, p. 30.

Ruiz Gómez, "La ilusión de la identidad en el imaginario medieval según Las Partidas", p. 243.

6 IBIDEM, p. 242.
} 
cuando actúa lo involuntario: en la selección de cuáles serán los elegidos definitivamente, porque asumir un elemento como identitario no es siempre un acto consciente, organizado y dirigido. Ello pone en tela de juicio la idea de una imposición de identidades colectivas desde un determinado grupo, generalmente "dominante" sobre el resto de la comunidad, como se ha defendido en muchos estudios al respecto 7 .

No hay duda de que, efectivamente, gran parte del proceso de construcción identitaria llevado a cabo por las ciudades a partir del siglo XIII estuvo dirigido por la oligarquía política y cultural urbana. Pero ¿fue siempre tan permeable el resto de la población a las leyendas, fábulas e imágenes proyectadas desde aquellos? No fueron escasos los intentos por parte de estos grupos dominantes de colocar o imponer determinados elementos para construir esa identidad que acabaron siendo rechazados y olvidados. Además, ¿no cabría la posibilidad de que algunas de esas imágenes que acabaron siendo identitarias procedieran originalmente de la población dominada y fueran adaptadas por la clase dominante? Nos centramos en muchas ocasiones en cómo afectaron las políticas y formas de vida de la oligarquía en el resto de la población y nos olvidamos muchas veces de la influencia que también se produjo de abajo arriba, de los dominados a los dominantes. Quizá el ejemplo de Madrid que analizaré más adelante es un claro ejemplo de cómo una idea es trasmitida desde las capas más populares, incluso desde lo que entonces eran consideraras una minoría, hasta convertirse en un elemento identitario de la ciudad. En el caso de Madrid, además, no fue una sola.

\section{La identidad a partir del territorio}

Son muchos y diversos los elementos que confluyen en la construcción de una identidad, ya sea individual, ya sea colectiva. En bastantes ocasiones se ha señalado la religión, la lengua, los grupos profesionales o las afinidades políticas como bases a partir de las cuales construimos nuestro yo social ${ }^{8}$. Hablo en presente, pero bien se podría hablar en pasado, porque muchos de estos elementos señalados también ejercieron tal función en tiempos pretéritos, incluida, lógicamente, la Edad Media. O quizá especialmente durante la época medieval, porque fue entonces cuando se multiplican los procesos identitarios. Todo parece indicar que fueron las ciudades las que protagonizaron las principales construcciones de identidad durante los siglos medievales, frente a un ámbito rural más diseminado y menos propenso a entrelazar sentimientos de pertenencia a un grupo concreto. En otras palabras, la documentación nos hace pensar en unas identidades más sólidas en las ciudades que en el campo. Las razones de ese protagonismo en la configuración de identidades habría que buscarlas quizá en el estatus de privilegio de

\footnotetext{
JARA FUENTE, "Sobre el concejo cerrado. Asamblearismo y participación política en las ciudades castellanas de la Baja Edad Media". Un repaso a las visiones sobre la construcción de las identidades en las ciudades castellanas la podemos encontrar en SOlóRzAno TELECHEA, "La identidad urbana y la Historia social de la política en el mundo urbano español y portugués en la Baja Edad Media".

8 Ruiz Gómez, "La ilusión de la identidad en el imaginario medieval según Las Partidas", p. 241.
} 
estas ciudades, o mejor dicho, en la idea de constituir una isla privilegiada frente al espacio rural que les rodeaba. Ellas eran el reducto de libertad frente a la servidumbre rural; la civilización y la cultura frente a la barbarie del campo; y la muralla, símbolo de orgullo de la ciudad, les protegía de todo aquello. Esa superioridad y diferenciación con respecto a lo demás constituyó el primer paso que puso en marcha la maquinaria de las identidades urbanas:

"El sentimiento de pertenecer a un espacio privilegiado dotado de un estatuto propio que les diferencia de los demás, y que se plasma en el fuero local y en las ordenanzas concejiles, es quizá el primer elemento que contribuye a otorgar identidad al colectivo social de un núcleo urbano".

Esa idea de superioridad y de privilegio fue, pues, la que puso en marcha la construcción de identidades. A partir de ahí, cada ciudad buscó sus elementos con los que fomentar y consolidar su imagen y prestigio. Fueron muchos los factores que sirvieron al individuo para construir una identidad y un sentimiento de pertenencia a una comunidad urbana. Aquella podía englobar a toda o la mayoría de la población, o bien sería compartida por solo un grupo dentro de esa población. En ocasiones, estas identidades 'grupales' entran en conflicto u oposición entre sí, o al menos, son contradictorias: la identidad cristiana con la identidad judía o mudéjar, la identidad de las clases gobernantes y oligarcas con la identidad de los pecheros, etc.

No obstante, me voy a centrar en las identidades transversales, comunes a toda o casi toda la población y que borra esas identidades enfrentadas; en definitiva, aquellas de las que toda la comunidad se siente partícipe. Encontramos, pues, elementos que son propios de toda la población de una localidad. Y así volvemos al punto inicial de este apartado, en busca de esos elementos que se convierten en símbolos no ya mayoritarios (como la religión o la lengua), sino prácticamente unánimes, que superan cualquier barrera diferenciadora.

En primer lugar, responderé de manera somera a una primera pregunta: ¿cuándo comenzó el fenómeno de la identidad urbana? Si echamos un ojo a los diferentes trabajos que han tratado de una u otra manera la cuestión, todo parece indicar que fue durante los últimos siglos medievales cuando estas identidades comenzaron a generarse, o, al menos, convertirse en una de las principales características del fenómeno urbano medieval.

A la hora de centrarse en los elementos con los que las ciudades crearon su identidad, se ha señalado habitualmente la honra como uno de las grandes protagonistas: "conceptos como servicio, honor, libertad, solidaridad, justicia, prosperidad, diligencia, honradez, aptitud, orden o concordia eran algunas de las categorías que se habían instalado ya definitivamente en el imaginario de las colectividades locales" ${ }^{\prime \prime}$.

\footnotetext{
Del Val Valdivieso, "La identidad urbana a finales de la Edad Media", p. 7.

10 Guerrero Navarrete, "La fiscalidad como espacio privilegiado de construcción político identitaria urbana", p. 57.
} 
¿Cómo construir esa honra? Una característica habitualmente señalada en estos casos fue la política del buen gobierno: la ciudad se ponía al servicio de sus habitantes para mejorar su calidad de vida y satisfacer sus demandas, ofrecer orden o seguridad ${ }^{11}$. Pero no fue la única estrategia. Varios son los autores y autoras que, haciendo una relación de cuáles pueden ser esos elementos comunes, señalan, entre ellos, el espacio o la tierra. Ruiz Gómez, por ejemplo, sitúa el espacio entre las herramientas esenciales para la configuración de una identidad colectiva ${ }^{12}$.

La tierra, el paisaje que rodeaba una localidad o sobre la que esta se asentaba, constituyó una herramienta con la que construir una honra, una identidad o un orgullo. Las comunidades que poblaron esos espacios, esos paisajes, se fijaron en ellos o en algunos de sus componentes para darles un cierto simbolismo, hasta el punto de que acabaron por constituir una característica propia, una marca de distinción con respecto a otras poblaciones y, con ellos, dotarse de personalidad ${ }^{13}$.

En realidad, la relación entre territorio e identidad viene de atrás, desde el origen mismo del asentamiento. Porque, a la hora de dar un nombre al espacio que habitaban y así significarlo e identificarlo, las poblaciones peninsulares del pasado, ya fueran andalusíes, cristianos, prerromanos o latinos, utilizaron habitualmente el territorio circundante. Fijándose en alguna de sus características o elementos, acababan dando un nombre a muchas localidades, aldeas o espacios, que sirvió para comenzar a construir una memoria colectiva, y que, en muchos casos, permanecería a pesar de los cambios poblacionales y lingüísticos. Es hora de adentrarnos en la toponimia para rastrear las huellas del territorio.

\section{Hidrónimos, orónimos y fitónimos: el nombre a partir del territorio}

"Y Adán dio nombre a todos los animales, a todas las aves del cielo y a todas las bestias del campo" (Génesis, 2, 19) ${ }^{14}$. Le faltó decir "y a todos los lugares". Desde sus orígenes, el ser humano ha sentido la necesidad de nombrar la tierra donde habita y por la que

\footnotetext{
11 Del Val Valdivieso, "La identidad urbana a finales de la Edad Media", p. 12. "Todas estas funciones, promovidas por los concejos, respondían al deseo de los gobiernos urbanos de transmitir su buen hacer, motivo por el cual promovieron las infraestructuras como fuentes y pozos, el acondicionamiento y la limpieza, el empedrado y la pavimentación" (Solorzano TelecheA, "La identidad urbana y la Historia social de la política en el mundo urbano español y portugués en la Baja Edad Media", p. 331).

12 "Los principales elementos que intervienen en la construcción de esta identidad son conocidos [...]: En primer lugar está la lengua con la que se comunican entre sí, y que a menudo difiere de la que hablan los otros pueblos que no pertenecen a la comunidad. A continuación, la tierra que habitan aporta una carga telúrica a su identidad, convirtiéndose en una referencia trascendente, porque allí han nacido y en ella reposan los restos de sus antepasados. En tercer lugar, el poder político, en torno al cual se teje la red de relaciones sociales y se desarrolla una dinámica de intercambios económicos. La verdadera importancia de estos tres elementos para la construcción de la identidad se comprueba cuando se analizan en su manifestación discursiva" (Ruiz Gómez, "La ilusión de la identidad en el imaginario medieval según Las Partidas", p. 241).

13 Del Val Valdivieso, "La identidad urbana a finales de la Edad Media", p. 9.

14 Cit. Ruiz De Loizaga, "Toponimia mayor y menor del Occidente de Álava en la Alta Edad Media", p. 249.
} 
transita y, de esa manera, ordenarla y socializarla ${ }^{15}$. Posiblemente los primeros pasos hacia el sedentarismo fueran los que generaron esa necesidad de reconocer la tierra, de identificarla y de comenzar a crear una memoria colectiva en torno a un espacio que comenzaron a sentirlo suyo ¿Son los antiguos megalitos una manera de nombrar los lugares? Al fin y al cabo, otorgar un nombre a un espacio también es una manera de dejar una huella para la posteridad.

En determinados periodos de la Historia, indagar sobre el origen de los nombres de cada localidad ha gozado de relativo éxito, tanto dentro como fuera del ámbito académico. Conocer por qué el pueblo, la ciudad o la aldea tiene ese nombre ha suscitado el interés de una parte importante de su población; un interés por conocer no sólo las raíces de su localidad sino también de su propia identidad y, en definitiva, la razón de su existir $^{16}$. La toponimia ha sido la encargada de dar un barniz académico a esta búsqueda; una disciplina en la que se hace indispensable la mezcla de conocimientos históricos, geográficos y lingüísticos cuando menos ${ }^{17}$.

Recoger en una lista los elementos que han sido utilizados por las diferentes poblaciones históricas de la Península para nombrar lugares y espacios resultaría una tarea ingente, muy lejos de las pretensiones de este trabajo y de mis propias capacidades. La variedad de topónimos resulta prácticamente inabarcable:

"Se entiende por nombres de lugar -o nombres geográficos-, en el sentido más amplio de la expresión, todos los nombres simples o expresiones compuestas que designan los lugares habitados, tanto antiguamente como en la actualidad [...] como también los lugares deshabitados; los nombres relativos al relieve [...], tanto de tierras interiores como de zonas costeras: montañas, llanuras, altiplanos, islas, cabos, calas, bahías; los nombres de lugar relativos al agua [...], sea ésta corriente o estancada, terrestre o marítima: mares, lagos, ríos, arroyos, torrentes, fuentes, lagos, pantanos; los nombres de las vías de comunicación $[\ldots]^{\prime 18}$.

15 García de Cortázar, "Espacio y hombre en la España norteña en la Edad Media”, p. 69.

16 Ruiz de Loizaga, “Toponimia mayor y menor del Occidente de Álava en la Alta Edad Media”, p. 249.

17 "El estudio de los nombres de lugar es una de las cosas que más ha desvelado la curiosidad de los eruditos e incluso la del pueblo en general. Es natural que sea así. Estos nombres se aplican a la heredad de la que somos propietarios, o a la montaña que limita nuestro horizonte, o al río de donde extraemos el agua para el riego, o al pueblo o la ciudad que nos ha visto nacer y que amamos por encima de cualquier otra, o a la comarca, el país o el estado donde está enmarcada nuestra vida colectiva. ¿Puede pensarse que el hombre, que desde que tiene uso de razón se pregunta el porqué de todas las cosas que ve y que siente, no se preguntaría sobre el porqué de estos nombres que todo el mundo tiene continuamente en los labios". Coromines, Estudis de toponímia catalana, vol. 1, p. 7.

18 Moreu-Rey, Els nostres noms de lloc, p. 10; cit. Tort i Donada, "Toponimia y marginalidad geográfica", p. 136. 
Un simple vistazo a algunos de los estudios toponímicos permite hacernos una idea de la enorme variedad de elementos que han sido utilizados para nombrar un lugar. No obstante, se puede sacar una primera conclusión: es el propio territorio, la naturaleza del espacio, el que se encuentra en la mayor parte de los procesos de nombramiento. Es verdad que encontramos con bastante asiduidad antropónimos: desde la Caesar Augusta, en honor al emperador, a la pequeña localidad de Pedro Muñoz, en Ciudad Real. Gran parte de los topónimos de origen beréber también están vinculados a los nombres de familias, como veremos más adelante. En otras ocasiones ha sido habitual usar algún tipo de edificio o estructura humana para construir el nombre. En estos casos suelen ser habituales las referencias a fortalezas y castillos: la propia Castilla; Catalunya; las diferentes Alcalá (procedentes del árabe qal'a), las numerosas localidades con el prefijo 'torre' (Torrelodones, Torrevieja, Torremolinos); pero también estructuras más cotidianas: Casarrubias, Casavieja, Molina del Segura, Castro Urdiales o los numerosos topónimos construidos a partir de puentes y sus diferentes formas lingüísticas ('pons/ pont', al-qantara), entre otros muchos ejemplos.

A pesar de ello, la inmensa mayoría de los topónimos peninsulares proceden de la propia tierra: montes, ríos, árboles y valles inspiraron a las diferentes poblaciones para dar nombre a su espacio. Es una máxima que parece repetirse en las diferentes sociedades históricas que han habitado la Península. Independientemente de su origen prerromano, latino, árabe, musulmán, castellano, catalán, etc., la mayoría de los topónimos hacen referencia a un accidente o elemento geográfico distintivo.

El relieve debió ser concebido en muchas ocasiones como lo suficientemente característico del lugar hasta el punto de darle una identidad. De esta manera, encontramos una gran cantidad de lugares con el prefijo latino 'mont(e)': los diversos Monforte a lo largo de España y Portugal; los Monteagudo que encontramos desde Cádiz a Navarra, el Montecarmelo de Madrid y así un largo etcétera. También de origen latino son las variantes de Foz/Hoz, considerado como "paso entre montañas, procedentes del latín faucem "angostura de un valle profundo" 19

La vegetación también ha servido como definidor de un espacio y los fitónimos resultantes constituyen una buena parte de los topónimos peninsulares. De entre ellos, son numerosos los casos en que el protagonista es un tipo concreto de árbol: higueras (Figueres, en Gerona; Figueroles, en Castellón; Higueruela, en Albacete; Higueruelas y La Font de la Figuera, en Valencia; o Lahiguera, en Jaén) ${ }^{20}$; álamos (La Alameda, en Soria; Alameda de Osuna, en Madrid o Alameda de Gardón, en Salamanca); pinos, que dan nombre a una gran cantidad de municipios (Pinar o Pinares); sauces, cuya raíz latina salicetum dio paso a Salcedo ${ }^{21}$, muy popular en las regiones de Asturias, Cantabria y Galicia. Manzanos, perales, naranjos y demás árboles frutales también son habituales en estos casos.

\footnotetext{
19 Ruiz de Loizaga, "Toponimia mayor y menor del Occidente de Álava en la Alta Edad Media”, p. 264.

20 BALlester, "Toponimia valenciana prejaimina", pp. 61-62.

21 Ruiz de Loizaga, “Toponimia mayor y menor del Occidente de Álava en la Alta Edad Media”, p. 269.
} 
Si hubo un elemento preferido a lo largo y ancho de la historia de la Península para otorgar un nombre a un espacio, ese fue, sin duda alguna, el agua. De ahí que se convierta en uno de los protagonistas de este trabajo. Contamos en la actualidad con una enorme cantidad de hidrónimos, a los que habría que sumar muchos otros que acabaron en el olvido. Las razones por las cuales esta alcanzó un gran protagonismo son bastante obvias: el agua es esencial para la vida. Sin ella ningún ser vivo puede sobrevivir. Esta función primordial explica la especial carga simbólica que esta tuvo en todos los pueblos históricos que ocuparon nuestro territorio. Pero la función del agua va más allá: permite el desarrollo de numerosas actividades económicas (pesca, tenerías, molienda, etc.) al tiempo que ha sido habitual el uso de ríos y arroyos como delimitadoras de un determinado espacio. Todo este protagonismo en la vida cotidiana se vería reflejado en su preeminencia a la hora de construir la base de una identidad.

“[...] la reconstrucción del tipo de vida propio del hombre primitivo, en el seno de una naturaleza todavía no transformada, nos ha de sugerir un elemento, el más básico para la vida, cual es el agua. No solo el más indispensable, sino el más orientador y delimitador en el territorio mediante su curso natural. El más abarcador porque, hasta puede recibir a los demás elementos en sí, dada la ocasión, mediante su reflejo, tras de sustentar en todos los vivientes la vida misma. Hasta contrapuesto a los demás por su estado triple: líquido, sólido y gaseoso" ${ }^{\prime 22}$.

La calidad, cantidad y diferentes formas en las que se manifestaba el agua fueron concebidas como característica peculiar de muchos espacios. Fuentes, arroyos, ríos y cualquier tipo de recurso hídrico que encontraron los primeros pobladores dieron distinción, o al menos a los ojos de aquellos, a la localidad, y ello había que recogerlo en la asignación de un nombre.

En muchas ocasiones, simplemente la presencia de un río o arroyo era lo que daba identidad al lugar: Guadarrama, Arroyomolinos o el propio Madrid, como se verá más adelante. Más habitual era la cantidad de aguas presentes en un lugar lo que lo convertiría en algún característico del mismo. No obstante, no en todas las ocasiones era la cantidad, sino, paradójicamente, la escasez de agua la protagonista del proceso. En este sentido, el geógrafo Joan Tort señalaba en un pequeño trabajo sobre la toponimia que "aparecen muchos más topónimos alusivos a "fuentes" en las zonas sin disponibilidad de agua que en las que disponen de ella (las primeras son, asimismo, las que tienen un carácter más periférico dentro de la comarca) ${ }^{{ }_{23} 3}$.

El mismo autor finalizaba recordando las palabras del autor Henri Dorion: "en pocos lugares se encuentran, como en el Sahara, tantos topónimos formados a partir de nom-

\footnotetext{
2 Martino Redondo, "Base científica de la nueva aproximación a la toponimia”, p. 234.

23 Tort i DonADA, “Toponimia y marginalidad geográfica”, p. 152.
} 
bres que aluden a la existencia de agua; y es que sólo aquello que es extraño y vital merece ser consignado, localizado, puesto en relieve, señalizado de un modo expreso"24. Muchos autores han visto en una gran cantidad de topónimos de origen prerromano la huella del agua: radicales como bal-pal-mir- harían referencia al preciado líquido o a acciones relacionadas con ella ${ }^{25}$. En este sentido, el polifacético Eutimio Martino señala una buena cantidad de radicales hidrómicos de origen celta como cea, que encuentra en el nombre de varias localidades como Acebedo en Asturias y Galicia, o como car-, que sirvió para nombres como Carrión, Cares o Carcedo ${ }^{26}$. Otros dos radicales prerromanos que el autor hace derivar del agua son nar- (Narcea) y, espacialmente, bal/pal, que asegura estar presente en muchos topónimos, entre ellos, en gran parte de los que comienzan por Val-, que habitualmente se considera, de manera errónea, derivado del latín ${ }^{27}$. E incluso algunos topónimos con el radical villa- no harían referencia a la villa latina sino procedería de pel > pelia $>$ billa, como en el caso de Villaverde ${ }^{28}$.

Por otra parte, la filóloga Rosa Pedrero Sancho considera igualmente el radical mira como un hidrónimo de origen prerromano, a partir de la variedad de ríos y localidades con dicho radical ${ }^{29}$. A partir de ahí se forjaron nombres como Mera (habituales en Portugal y Galicia) o las más famosas Miranda (de Ebro en Burgos y de Duero en Portugal) y, posiblemente sus derivados Aranda o Arganda; todas ellas con el sufijo también hidrómico $-\mathrm{nta}^{30}$. Otros autores han señalado la raíz mar- como otro de los hidrónimos prerromanos usados de manera habitual "que sirve para designar el «agua»y, más concretamente, el «agua detenida, quieta, estancada» $[\ldots]^{1{ }^{31}}$. Encontramos esta raíz en topónimos de zonas como Cáceres y su arroyo El Marco $^{32}$ o como Asturias o Galicia.

La llegada de Roma a la Península Ibérica y la latinización de la población autóctona hicieron que muchos de esos nombres mutasen en cierta medida a formas más acordes al nuevo idioma. Hidrónimos celtas como awo- ('río'), na- ('fluir'), nebh- ('húmedo') y posiblemente lei- ('fluir' y del derivara el latín libare) fueron asumidos y transformados para dar nuevos nombres a las diferentes localidades y espacios, en este caso, en el noroeste peninsular: Avobriga, Navia, Nebius, Libora o Iulia Libica, etc..$^{33}$. Del ya

\footnotetext{
24 Cit. ToRT i DonadA, “Toponimia y marginalidad geográfica”, p. 153.

25 "[...] fluir, manar, etc. O bien con adjetivos descriptivos del curso de agua" (Pedrero SANCHO, "El hidrónimo prerromano Mira", p. 370).

26 El autor ve incluso en muchos topónimos 'García' como compuestos de ambos radicales car y cía/cea (Martino Redondo, “Base científica de la nueva aproximación a la toponimia”, p. 239).

27 "Se le ha confundido en España de forma crónica con val, dependiente de vallis, por la doble vía de la evolución fonética $p>b$ y de la asociación física del valle con el río, asociación también mental en consecuencia" (Martino Redondo, "Base científica de la nueva aproximación a la toponimia”, p. 235). De esta manera, este radical estaría detrás de nombres que serían adoptados por el mundo latino: Valdefuentes, Valdeburón, Palantia/Palencia, Palanquinos, Illos Pelios/Los Espejos y así una larga lista de topónimos.

28 Martino Redondo, "Base científica de la nueva aproximación a la toponimia", p.239.

29 Pedrero Sancho, "El hidrónimo prerromano Mira", p. 362.

30 IBIDEM, p. 365.

31 MaÑas NúÑEz, “Sobre los hidrónimos Marco y Marimarco de Cáceres”, p. 345.

32 IBIDEM, pp. 344-345.

33 Curchin, "Los topónimos de la Galicia romana: nuevo estudio", pp. 113-114.
} 
mencionado radical prerromano pal-derivaron las formas latinas palus ('laguna') pluo ('llover') ${ }^{34}$ y pleu ('fluir'), base de nombres como la famosa Complutum. Junto a estas raíces prerromanas hallamos en las fuentes latinas una gran cantidad de topónimos con nombres propiamente latinos. En la Hispania romana fueron relativamente frecuentes nombres compuestos con la palabra Aquae, si bien muchos de ellos en la actualidad han desaparecido: Aquae Flaviae (Chaves) Aquae Querquennae, en Ourense, Aquae Bilbilitanorum, etc.

Muchos más numerosos son los topónimos creados a partir de la palabra latina fonte. Son innumerables las localidades y espacios con nombres compuestos por Fuente y sus derivados (font, fon, fuen, etc.); muchos de ellos remiten a época latina y otros ya al periodo romance. Fontecha (compuesto por fonte y tecta - 'fuente cubierta' o de fonticula 'fuente pequeña' ${ }^{35}$ ), Fuenlabrada, Fontarrón, Cifuentes (procedente de Centum Fontes), Fuente del Rey, Fontanillas, y así un largo etcétera.

Junto a estas fuentes, los pozos, derivación latina, también han sido muy habituales para nombrar un espacio: Pozuelo, Ciempozuelos o Pozo del Tío Raimundo, en Madrid; Pozo de Urama, en Palencia; o Pozo Cañada en Albacete son solo algunos ejemplos de una enorme lista.

La llegada del mundo islámico aumentó significativamente el número de hidrónimos peninsulares. Un proceso lógico si tenemos en cuenta el gran simbolismo que adquirió el agua en el islam, una religión, no olvidemos, nacida en plena Arabia. Un simple vistazo basta para hacernos una idea de la enorme cantidad de hidrónimos que poseemos de herencia musulmana. Quizá el más reconocido sea la raíz árabe wadi- para dar nombre una buena parte de nuestros ríos: Guadalquivir (wadi l-kabir), Guadiana (mezcla de dos raíces distintas, el árabe wadi y el prerromano -ana, ambos sinónimos de 'río'), Guadalhorce (wadil-jurs), algunos de los cuales también acabaron usándose para nombrar un espacio o localidad, como Guadarrama ( $W \bar{a} d \bar{l}-r-R a m l)$ o Guadalajara (wādi al-haŷarah) o Guadalupe (wad al-luben). Junto a ellos, hidrónimos no tan conocidos como bir, 'pozo': Gibalbín (Yabal bir o Monte del Pozo) ${ }^{36}$ o Albires (al-bir) en León.

El componente bereber, otro protagonista de este estudio, también se hizo presente con la llegada del islam. La huella norteafricana es menos conocida que la árabe, debido quizá al poco desarrollo del estudio de estas lenguas pre-islámicas en nuestra historiografía, teniendo en muchos casos que recurrir a estudiosos en lengua francesa. No obstante, contamos con varias aportaciones de nuestro país, como Helena de Felipe, cuya labor en este campo resulta esencial. Los estudios de ambos lados de los Pirineos y del Estrecho han permitido sacar a la luz el origen bereber de muchos topónimos bereberes, lo que nos ha hecho ver que son más numerosos de lo que se podría pensar ${ }^{37}$. Y podrían serlo

\footnotetext{
Martino Redondo, "Base científica de la nueva aproximación a la toponimia", p. 235.

Ruiz de Loizaga, "Toponimia mayor y menor del Occidente de Álava en la Alta Edad Media”, p. 263.

Martín Gutiérrez, "Análisis de la toponimia y aplicación al estudio del poblamiento", p. 267.

37 Jaime Oliver abría la puerta a la posibilidad de que a través de determinados sufijos, como los de -ana (Berberana) o-itz (Orbaiz) se podría rastrear la huella bereber en muchos topónimos peninsulares (OLIVER Asín, En torno a los orígenes de Castilla, pp. 28 y 31).
} 
aún más, especialmente en el caso de los hidrónimos. En este sentido, Javier Jiménez Gadea señalaba la posibilidad, abierta por Miquel Barceló, de rastrear asentamientos bereberes a través de la relación de los topónimos de una determinada zona con las prácticas hidráulicas propias de la región de su procedencia -el Magreb-38. Antes, Jaime Oliver, siguiendo a Julián Rivera, consideró frecuente el uso de la palabra bereber tit en varios topónimos y estaría relacionado con algún tipo de manantial o fuente de agua ${ }^{39}$.

\section{Madrid: el agua como identidad}

La hoy capital de España fue en sus orígenes una pequeña medina islámica y, poco después, una mediana villa castellana. Esa localidad de reducidas dimensiones comenzó a construir su identidad a partir del espacio que ocuparon sus habitantes. Quizá ya la primera comunidad bereber que se asentó en una de las dos colinas originarias de Madrid, se fijó en el agua para socializar ese espacio, y crear a partir de ella una memoria colectiva que ha ido perdurando a lo largo de los siglos, desde aquella pequeña aldea campesina a lo que en la actualidad es la ciudad más grande de la Península Ibérica. Le dieron un nombre, Mayrit, que reflejaba la importancia que tendría el líquido en la identidad madrileña.

El protagonismo del agua en la construcción de la memoria colectiva madrileña no se limitó al nombre. Aparcaré, por el momento, la construcción del topónimo y avanzaré hasta la Baja Edad Media para fijarme, una vez más, en el fenómeno de la identidad urbana que por entonces se estaba gestando. Muchos fueron los factores y elementos que usaron las ciudades para construir su prestigio y personalidad: episodios históricos, guerras, héroes vinculados a la localidad, el embellecimiento de sus calles y edificios. Casi cualquier elemento era susceptible de ser elegido para enorgullecerse. También el tamaño de las ciudades y el número de habitantes marcó, en la mentalidad bajomedieval, el prestigio de un centro urbano ${ }^{40}$.

Sin embargo, muchas localidades no podían seguir el ritmo marcado por las grandes y ricas urbes de la Península. No todas ellas tenían la capacidad económica suficiente como para mandar construir grandes templos, hermosas fuentes; ni tenían un pasado glorioso del que presumir ni las dimensiones de Burgos, Sevilla o Toledo. Entre esas localidades, se encontraba Madrid. Su precaria economía le impedía desarrollar una gran política urbanística y le resultaba privativo llevar a cabo el embellecimiento de sus calles. Sus reducidas dimensiones tampoco le aportaban una base para construir su prestigio. En esa situación, Madrid debió buscar algún elemento que le pudiera dar personalidad. Lo encontró en uno de sus grandes recursos: el agua. La Villa contaba desde sus

\footnotetext{
3 Jiménez GadeA, Los asentamientos beréberes en al-Andalus, p. 210.

39 Cit. Oliver Asín, En torno a los orígenes de Castilla, p. 39.

40 "Parece claro que el número de vecinos es un dato relevante en lo que se refiere a la jerarquización de villas y ciudades, no solamente en el marco de la historiografía contemporánea, sino en el de la propia mentalidad bajomedieval" (DEL VAL VALDIVIESo, "La identidad urbana a finales de la Edad Media", p. 11).
} 
orígenes una gran cantidad de fuentes, arroyos y manantiales en un territorio, el centro peninsular, donde el líquido elemento no era precisamente abundante. Esa realidad, ese contraste con respecto al territorio que le rodeaba fue el que le sirvió para construirse una personalidad propia. Madrid, a diferencia de muchas otras localidades del entorno, podía ofrecer grandes cantidades de agua a sus habitantes y visitantes: Fuentes de San Pedro, pilares de la Villa, la Alcantarilla y Caños Viejos al sur, y fuentes de Valnadú, Caños del Peral, fuente de la Priora-Santo Domingo y Leganitos al norte; nueve veneros principales para un recinto de unas 33 hectáreas, a los que sumar las situadas en las proximidades del recinto, como Fuente Forosa, Fuente Castellana, Amaniel o Fontalba, junto a otros manaderos secundarios que escaparon a la documentación.

A la cantidad se otorgó al agua madrileña otra cualidad con la que reforzar aún más ese orgullo: la calidad. Es por todos conocido lo que presume a día de hoy una madrileña o un madrileño del sabor y calidad del agua de Madrid. La razón es la eficiencia y labor del Canal de Isabel II, convertido en un orgullo madrileño desde su construcción en el siglo XIX. Pero esa imagen de aguas extraordinarias viene de atrás, de cuando madrileños y madrileñas bebían de aguas diferentes a las actuales. Ya en Las Relaciones topográficas mandadas hacer por Felipe II podemos ver a un Madrid del siglo XVI que presumía de sus aguas:

"Fui sobre agua edificada/ mis muros de fuego son. / Esta es mi insignia y blasón.

[...] Tiene las más y mejores fuentes, y de mejor agua que se hayan hasta agora visto en el prado, que dicen de Sant Hieronimo, hay cinco fuentes de singular arteficio, que tiene en cada uno una vacía de piedra berroqueña, que tiene de diámetro diez pies, y media vara de borde, vaciadas por de dentro, asentadas sobre un balaustre de cinco pies de alto. También tiene otro abrevadero con dos caños, de la misma piedra berroqueña, que tiene de largo setenta pies, y de nuevo más de doce, el uno de los caños sale por la boca de un delfín con una letra que dice bueno. El otro sale por la boca de una culebra, y a ésta rodean otras dos arrevueltas con una esfera, que tiene un espejo de bronce, y en el medio dice VIDA Y GLORIA. Luego a la mano derecha hay otra fuente de cinco caños. A la mano izquierda ay otra, que tiene más de cincuenta caños de agua, que paresce que siempre está lloviendo. Más distante de la que a ésta responden, sale otra fuente con otros cuatro golpes de agua. Al fin del Prado está otra con tres golpes de agua. También hay otra fuente ochavada que mira a Sant Hierónimo que tiene otros cuatro años y son éstas las fuentes de Leganitos. Lavapiés, los Pilares Viejos, las fuentes del Peral y de la Priora, en tanta abundancia que sobra agua para todo lo necesario, y esto sin la fuente tan experimentada para la salud de San Isidro, cuyo cuerpo está en la iglesia parroquial de San Andrés"41.

${ }^{41}$ Relaciones topográficas mandadas hacer por Felipe II, pp. 359-360. 
La raíz de esa imagen de aguas extraordinarias madrileñas se puede encontrar antes de la llegada de la Corte. En realidad, el simbolismo especial otorgado al agua es una práctica muy habitual en el panorama peninsular e incluso de toda Europa: en la documentación de las diferentes localidades medievales era muy habitual encontrar referencias a fuentes, pozos o arroyos con un valor extraordinario, en algún caso con poderes mágicos, generalmente taumatúrgicos o sanadores. Bien por su sabor, bien por su lejanía con respecto a la localidad (y por tanto, dentro de ese mundo propenso a la magia como era el bosque), lo cierto es que muchas fuentes, tanto en territorio cristiano como en territorio andalusí, adquirieron especial fama.

No fueron pocas las ciudades peninsulares que usaron ese simbolismo a partir de los siglos XIII y XIV para construir sus identidades colectivas. Cuando la historia no ayudaba y no ofrecía ningún episodio relevante con la que sentirse orgulloso, el territorio cubría ese vacío. En su afán de distinguirse de las demás, muchas localidades subrayaron la abundancia y calidad de sus aguas ${ }^{42}$. Madrid fue una de ellas ${ }^{43}$.

Buscar los orígenes de la relación simbólica entre Madrid y su agua resulta bastante complicado. A día de hoy carecemos de datos que puedan aportar una hipótesis sólida. Es inevitable dirigir la mirada hacia los primeros pasos de la localidad, cuando, precisamente, se generó su nombre: Mayrit. El fuerte carácter simbólico del agua en el imaginario islámico podría hacernos pensar que ya desde su nacimiento adquirió un gran protagonismo. Más aún si cabe al tener en cuenta que la primera población madrileña procedía del norte de África, donde posiblemente el agua ya contaba de por sí con una relevancia especial. Además, no hay que olvidar que esa primera población fue campesina. Y quizá no haya una comunidad más consciente de la importancia del agua que aquella que la utiliza para poder realizar su principal actividad. De ahí, que aquella originaria sociedad bereber -campesina, norteafricana e islamizada- utilizara el agua para nombrar a su espacio y darle una característica espacial: Mayrit. Su nombre, por tanto, se convierte en nuestro principal indicio para pensar en una estimación especial hacia el agua de su territorio desde prácticamente los orígenes de la ciudad.

Avanzando en los siglos, y convertida Madrid ya en una villa castellana, es probable que en su población el agua siguiera teniendo un papel relevante. La causa principal sería la permanencia de una fuerte tradición bereber e islámica en el sistema de mentalidades madrileño. Quizá ello constituiría la base con la que Madrid se lanzó a esa carrera de construcción de prestigio y honra a partir del siglo XIV. El hecho de que su relación especial con el agua ya viniera de tiempo atrás posiblemente explique por qué se asentó en la mentalidad colectiva madrileña la imagen de su relevancia hidráulica y no otras fábulas y leyendas que comenzaron a elaborarse sobre sus orígenes prerromanos o clásicos. Fue entonces cuando comenzó a forjarse lo que acabaría siendo el lema de Madrid: "Fui sobre agua edificada, mis muros de fuego son".

\footnotetext{
42 Muñoz Fernández, "Metáforas del agua en la cultura urbana madrileña", p.163.

43 IBIDEM, p. 163.
} 
Sin pretender entrar en detalles de cómo surge ese lema ${ }^{44}$, lo que quería resaltar en este momento era el papel que tuvo el agua en la creación de la identidad madrileña a finales de la Edad Media y que poco después se vería reforzado gracias a los diferentes cronistas de la Villa de época moderna. Cuatro siglos más tarde, los y las habitantes de Madrid siguen defendiendo la calidad de las aguas de su ciudad.

\section{La formación del topónimo Madrid}

En este último apartado, me dispongo a escudriñar el nombre de Madrid, un topónimo que todavía hoy genera dudas y cuyo significado todavía no ha quedado completamente claro. Volver a indagar sobre una cuestión que ha generado tanto debate pueda resultar poco relevante para muchos autores, pero comprender el topónimo en su totalidad es imprescindible para completar el conocimiento del pasado madrileño y del grupo humano que lo protagonizó. Cerrar en falso un debate que aún deja muchas dudas es dejar de conocer a dicha población. Y ese es el caso de Madrid.

El objetivo en este momento es buscar y comprender la formación del topónimo. Para ello me adentraré en la complicada historia de los orígenes de Madrid. El mayor obstáculo se encuentra en el hecho de que todavía hoy quedan algunas lagunas sobre el nacimiento del asentamiento madrileño. Ello ha motivado la aparición continua de diferentes teorías que han intentado dar respuesta a la cuestión, independientemente de si, en ocasiones, no contaban con las condiciones adecuadas para hacerlo de manera científica. Algunas de estas teorías se vieron influenciadas en mayor o menor medida por ideas e imágenes preconcebidas y construidas a lo largo de los siglos. Durante siglos, la imagen creada en torno a Madrid distaba mucho de su realidad. No era fácil compaginar la capital de un Estado o de un Imperio con sus orígenes humildes, y mucho menos en épocas en las que un pasado heroico era un valor seguro de prestigio. La modestia de sus orígenes no era la mejor carta de presentación para la Villa. Por ello, se fue construyendo todo un conjunto de fábulas y leyendas fundacionales que, lejos de buscar la verdad sobre el pasado, tenían como objetivo ocultarlo y sustituirlo por otro mucho más glorioso para la mentalidad del momento. El pasado de Madrid comenzaba así a desvirtuarse. Algunas de las propuestas de entonces, poco fundamentadas, acabaron en obras académicas y de divulgación y terminaron por convertirse en verdades absolutas que han sido difíciles de erradicar. Para adaptarse a su situación de sede de la Corte imperial, "Madrid tenía que ser griega y romana"45. Fue a partir de la decisión de Felipe II cuando comenzó un verdadero interés por conocer el pasado de Madrid, incluido el origen del topónimo. Surgió entonces un continuo debate entre las diferentes propuestas en torno a su construcción y significado. Todas ellas guardan un valor escondido: independientemente de su rigor científico, no

\footnotetext{
44 Un buen análisis del origen de este lema lo podemos encontrar en MuÑoz Fernández, "Metáforas del agua en la cultura urbana madrileña".

45 Oliver Asín, Historia del nombre "Madrid", p. 222.
} 
dejan de mostrar una corriente de pensamiento concreto, determinado por el contexto político y cultural del momento en que se desarrolló. Es decir, son huellas de una realidad ideológica dominante en un determinado momento ${ }^{46}$.

Mi intención no es la de hacer un repaso pormenorizado por todas y cada una de las teorías que surgieron en torno al nombre de Madrid. Ello supondría una tarea demasiado amplia para las pretensiones del presente trabajo. Por ello, he querido destacar las que he considerado más representativas y que, creo, mejor ayudan a acercar al lector y lectora al complejo debate suscitado en torno al origen etimológico de Madrid, centrándome especialmente en aquellas posturas que defendieron, con más o menos acierto, sus raíces árabes.

\subsection{Las diferentes propuestas históricas}

El debate en torno al origen del nombre Madrid se inició en el siglo XVI. Si tenemos en cuenta la imagen creada en torno al pasado de la ciudad en los siglos posteriores, podría parecer chocante que algunos de esos primeros eruditos que participaron en ese debate defendieran ya por entonces la teoría arabista, aunque con grandes matizaciones. "Lugar de cascajo, pedregal o lugar de piedras" o "escuela donde deprenden". Esos fueron los primeros significados atribuidos al topónimo madrileño por parte de la opción arabista de los que tenemos noticias. Los elaboró el jerónimo fray Pedro de Alcalá a caballo entre los siglos XV y XVI a partir de las dos palabras árabes que consideraba podrían ser el origen del topónimo: mahyara o majdara/madrasa ${ }^{47}$. Como veremos, no estaba excesivamente mal encaminado. Sea como fuere, el escritor humanista Juan López de Hoyos, el poeta y dramaturgo Gabriel Lobo de la Vega o el filólogo granadino Francisco López Tamarid también defendieron durante el siglo XVI que fue la población islámica quien elaboró el nombre de Madrid, si bien cada uno de ellos le dio un significado diferente ${ }^{4}$. Durante el siglo XVII, la opción arabista seguía siendo la más aceptada y eruditos del instituto de los Reales Estudios de San Isidro o Colegio Imperial de la Compañía, religiosos como fray Juan Carrillo o el dominico Jaime Bleda y cronistas como Alonso Núñez de Castro, siguieron defendiéndola ${ }^{49}$.

\footnotetext{
46 "En tiempos cervantinos, este origen árabe de la villa se intentó ocultar por los Austrias y sus propagandistas, tratando de "dignificar" los orígenes de la recién elegida capital hispana. En aquel tiempo, tal dignificación pasaba por borrar todo pasado bárbaro (medieval), y más si éste era musulmán, pues eran tiempos tridentinos y de lucha contra el turco. Una de las estrategias pasó por el recurso a la apoyatura terminológica, buscando inspiración en la mitología y en la Historia Antigua. Así, Madrid fue rebautizada en los círculos intelectuales como Mantua Carpentanea" (Lorenzo Arribas, "Mantua Carpetanea", p. 7537). 47 Cit. Oliver Asín, Historia del nombre "Madrid", pp. 218-219.

48 Juan López de Hoyos lo tradujo por "lugar ventoso de ayres subtiles" (Cit. Lorenzo Arribas, "Mantua Carpetanea", p. 7538), Lobo de la Vega por "horcajo" (Cit. Quintana, Historia de la antigüedad, nobleza y grandeza de la Villa de Madrid, p. 21), mientras que López Tamarid recuperó el vocablo mahyara del fraile jerónimo y lo tradujo por "terrones de fuego" (Cit. Oliver Asín, Historia del nombre "Madrid”, p. 219).

49 A comienzos de ese siglo, Covarrubias escribía: "Lo que se tiene por más cierto es ser nombre Arábigo: y según los peritos en la lengua, dizen, que vale tanto Madrid, como terrones de fuego: y esto por
} 
Frente a esta postura se postuló otro grupo de ensayistas que defendían un origen etimológico anterior a la llegada de los musulmanes, por lo general dentro del mundo clásico: el griego Matrylion, impuesto por supuestos fundadores helénicos o varios ejemplos romanos fueron propuestos como alternativa, más adecuada para esos tiempos ${ }^{50}$.

En realidad, este primer debate era puramente de carácter etimológico, pues los planteamientos arabistas no contenían en realidad una propuesta diferente a los orígenes de Madrid como población. Unos y otros coincidían en que el nacimiento de la Villa se produjo dentro del mundo clásico y las únicas diferencias estribaban en la naturaleza del nombre. Así, por ejemplo, Juan López de Hoyos, afirmaba que Madrid era conocido en época romana como Mantua, nombre que acabó por desaparecer en favor de la versión árabe ${ }^{51}$. Ávidos de encontrar en las raíces madrileñas un pasado acorde a la dignidad del momento (el mundo clásico), se dio el pistoletazo de salida a las diferentes propuestas sobre la fundación de la Villa, sacadas algunas de las mentes más fantasiosas. En una obra anónima publicada en 1603 por el Colegio de la Compañía de Jesús afirmaba que Madrid nació por deseo del legendario príncipe griego Ocno Bianor, hijo de Tiberio, quien quería establecerse en la Península Ibérica ${ }^{52}$. La ciudad que fundaría recibiría el nombre de Mantua, en honor a su madre Mantho ${ }^{53}$.

El siglo XVIII trajo consigo las primeras posturas críticas hacia estas fundaciones legendarias y de fantasioso personajes. No obstante, fue una crítica de forma y no de fondo, pues siguió prevaleciendo la vinculación con la Mantua Carpetana. Pero

estar fundada sobre pedernales, que heridos echan de sí fuego. Y también la interpretan madre del saber, por estar allí las escuelas de las ciencias en tiempos de los Moros" (Covarrubias, Tesoro de la lengua castellana o española, p. 532). Otras propuestas de este siglo se pueden ver en Quintana, Historia de la antigüedad, nobleza y grandeza de la Villa de Madrid, y OLIVer Asín, Historia del nombre "Madrid". En esta obra se puede encontrar la propuesta bastante fantasiosa del cronista de Felipe IV, quien consideraba el significado de Madrid como "Pueblo del Sol", según Jaime Oliver, con el vocablo masriq y este, a su vez, con sarq o Sol (p. 221)

50 Jerónimo de Quintana es quizá uno de los que más empeño empleó para refutar la corriente arabista proponiendo Maiorito como origen del topónimo. Era el nombre que supuestamente usaron las autoridades romanas a la ciudad una vez que ampliaron el recinto que había fundado la población griega: "[...] claramente se verifica que el nombre de Madrid no es Arábigo, sino deduzido y derivado del nombre latino Maiorito, como se dexa ver de las mutaciones que ha tenido en diferentes tiempos, que quedan referidas" (Quintana, Historia de la antigüedad, nobleza y grandeza de la Villa de Madrid, p. 21).

51 La vinculación entre la Villa y la Mantua Carpetana había nacido a finales del siglo XV, cuando Lucio Marineo Sículo y Gonzalo Fernández de Oviedo comenzaron a forjar la leyenda fundacional de Madrid: "Deseo que la memoria de la villa mantuana, en la región carpetana sea siempre aumentada [...]" (Cit. Lorenzo Arribas, "Mantua Carpetana", p. 7538).

52 IBIDEM, p. 7538.

53 Quintana, Historia de la antigüedad, nobleza y grandeza de la Villa de Madrid, p. 10. Para dar mayor prestigio a la fundación, la mitología matritense quiso situar a la familia del príncipe Ocno entre los presentes en la Guerra de Troya (Lorenzo Arribas, "Mantua Carpetana", p. 7538). No fue la única opción que se barajó. Aunque de menor repercusión, también se usó entre los eruditos el término de Ursaria o Viseria, en honor a uno de los animales supuestamente más característicos del paisaje madrileño: los osos. Esta propuesta arrancaría de una edición en latín publicada de 1491 de las tablas astronómicas de Ptolomeo en la que aparecería una anotación manuscrita "Mantua (Viseria olim) Madrid"; anotación que se repitió en las ediciones posteriores (SAnz García, "Madrid. Mitos y utopía”, pp. 46 y 49). 
comenzaron a surgir propuestas interesantes para nuestro objetivo: Miguel Casiri, por ejemplo, que defendía Maioritum como epónimo de Madrid, consideraba Mayrit como forma intermedia y se atrevió a ver en la voz árabe un significado de conducción o acueducto $^{54}$, relacionándolo por primera vez con el agua. En este mismo sentido se manifestó Juan Antonio Pellicer, quien tradujo en 1791 Magerit como 'venas' o flujos de agua, al considerarlo como una unión entre ma (agua) y gierit (flujo) ${ }^{55}$. La querella se enriqueció durante el siglo XIX, al abrir de manera definitiva el debate sobre el nacimiento de la ciudad. El espíritu crítico prevalecía y la actitud generalizada tendía a desenmascarar las diferentes fábulas que se crearon en torno al nacimiento de Madrid. Eruditos como José Amador de los Ríos y Juan de Dios de la Rada y obras como el Diccionario Madoz se dedicaron a recopilar todo este tipo de leyendas fundacionales para someterlo a la crítica decimonónica ${ }^{56}$.

Desde el punto de vista exclusivamente etimológico, el debate sobre Madrid pareció dar un giro de 180 grados al perder peso la raíz árabe en favor de una vertiente latinista, que buscaba una vez más en el mundo latino las raíces del nombre. Ya no se buscaban orígenes grandilocuentes, una vez pasado el fervor imperialista, pero todavía se puede apreciar a estas alturas un rechazo a la posibilidad islámica. Entre las nuevas propuestas, la de Ángel Casemiro de Govantes tendría a la larga una gran trascendencia. El académico riojano esgrimió por primera vez la palabra Matrice como raíz de Madriz, localidad perteneciente a San Millán de la Cogolla, y lo hacía extensible a la capital del Estado, aprovechando para atacar las teorías arabistas de su nombre: “[...] se ve con qué poco fundamento los etimologistas de la Corte de Madrid quieren hacer árabe este nombre, fundándose en escrituras latinas en las que por elegancia se alternaban las verdaderas denominaciones de los pueblos" ${ }^{57}$.

\footnotetext{
54 Cit. Oliver Asín, Historia del nombre "Madrid”, p. 225.

55 Si bien las tesis arabistas parecían las predominantes en cuanto a la etimología, no parecía haber consenso claro en torno al origen físico del asentamiento, por lo que muchos autores optaron por no mostrar convencimiento por las teorías clásicas, visigodas o islámicas: "No se puede afirmar otra cosa que Madrid es un pueblo muy antiguo” escribió José Antonio Álvarez y Baena en 1785 (SANZ GARcía, "Madrid. Mitos y utopía", p. 74).

56 Ello no significa que durante ese siglo XIX no apareciesen teorías que hoy en día podría considerarse cercanas a la fantasía. Quien fuera miembro de la Real Academia de la Historia, Miguel Cortés y López, negaba en 1835 vinculación alguna entre Madrid y la Mantua Carpetana y la establecía con el mundo romano, relacionándolo con la Miacum del Itinerario Antonino, aunque de origen hebreo o fenicio (SANZ GARCÍA, "Madrid. Mitos y utopía”, p. 45); una propuesta que tuvo bastante aceptación en el siglo siguiente. 57 Cit. Oliver Asín, Historia del nombre "Madrid”, pp. 231-232. Curiosamente, su propuesta fue rechazada por los eruditos del momento. El siglo XX tampoco trajo en sus primeras décadas grandes avances en el estudio, ya que siguió triunfando la postura no arabista, buscando orígenes celtas, como el Padre Fita - de Magán-o germánico, como Jungfer -de Medarid-. Unas teorías que hoy podrían parecer sorprendentes, pero que reflejan la realidad del momento: el triunfo de las visiones pro-germanistas y de exaltación de lo godo que marcaron el comienzo del pasado siglo en muchos ámbitos de la vida cotidiana, incluido el mundo académico.
} 


\subsection{La propuesta del profesor Oliver Asín. La victoria de la opción arabista}

Un punto de inflexión se dio a mediados del siglo XX. Hasta entonces, la cuestión del topónimo Madrid no había ofrecido muchas novedades. Antes de cumplirse el ecuador del siglo, Ramón Menéndez Pidal llegó a la conclusión de que no había relación alguna entre la forma actual y Mayrit: "Pero estas dos formas no son las únicas y por añadidura son irreductibles la una a la otra, por más que se ha intentado el identificarlas mediante procedimientos aventurados e inaceptables" ${ }_{58}$. Se trataba de dos nombres con distinta evolución fonética. Tras el historiador, surgió la figura de Jaime Oliver Asín, cuya obra sin duda supuso un antes y un después en la Historia madrileña. El filólogo consagró todos sus conocimientos a intentar esclarecer de manera definitiva el origen y significado del nombre de la Villa. Para ello no dudó en seleccionar aportaciones de quienes habían tratado la cuestión con anterioridad para darle una forma lógica y convincente. $\mathrm{Y}$, en cierto modo, lo consiguió, no sin cometer una serie de errores -comprensibles- que él mismo acabó por reconocer: del libanés Miguel Casiri tomó el significado último de la forma árabe; de Govantes la raíz latina de Matriz, y de Menéndez Pidal la disociación entre las voces árabe y latina. A ello aportó su propio conocimiento de la lengua árabe, elaborando así unos planteamientos que supusieron un enorme impulso en el conocimiento no solo de la cuestión sino del Madrid medieval en su conjunto. Pero como decía, no estuvo exento de errores. Porque en un primer momento, esgrimió un origen etimológico doble: por un lado, el árabe Mayrit, opción que finalmente ha triunfado, y el latino Matrice, que décadas más tarde él mismo descartaría. Errores comprensibles porque en cierta medida era heredero de una larga tradición historiográfica que buscaba una raíz latina a todo lo relacionado con Madrid y que todavía entonces imperaba. En definitiva, el historiador e historiadora son hijos de su tiempo.

Sea como fuere, los planteamientos de Oliver Asín son muy conocidos debido a la gran difusión que tuvieron sus propuestas. Estas consistían en ese doble origen de la palabra Madrid, que escondía detrás de sí un doble nacimiento de la ciudad. Siguiendo al autor, el primero en ser elaborado fue la versión latina: Matrice, en el dialecto tardorromano que hablaba la comunidad visigoda que se asentaría en la colina sur o de Las Vistillas. En su origen, pues, Madrid fue un pequeño recinto visigodo. La razón de ser de este primer nombre era el agua. Con dicho nombre, la comunidad quería honrar al pequeño curso fluvial -llamado posteriormente San Pedro- que permitió su asentamiento y del cual se abastecería: el arroyo matriz o madre. La decisión de Muhammad I de levantar un castillo en la colina norte supuso la llegada de un grupo humano de tradición islámica, el cual decidió dar un nombre a su propio emplazamiento: Mayrit. Según el autor, este nuevo nombre se dio como resultado de una adaptación del sentido -que no de la palabra-, al árabe de la versión latina: el nuevo topónimo respetaba la relación existente con el agua, aunque sustituyendo su raíz. Esta procedía a partir de entonces de la palabra

58 Menéndez PidAl, Ramón, "La etimología de Madrid y la antigua Carpetania”, p. 7. 
árabe mayra. Barajando las posibles acepciones dadas a la palabra ${ }^{59}$, el autor eligió la de "canal subterráneo" como el verdadero significado de Mayrit, debido a las supuestas canalizaciones con las que el asentamiento se nutría de agua. El sufijo -it parecía crear algo más de problemas, pero Jaime Oliver lo solucionó considerándolo procedente del latino etum. Con ello quedaba a salvo la fundación visigoda/latina y la presencia cristiana en Madrid desde sus orígenes, recogiendo así la tradición historiográfica de su propio momento. A este término le dio el significado de abundancia y, de este modo, Mayrit pasaba a significar algo así como "lugar abundante de mayras o canales"

“[...] manejando el Vocabulario de Pedro de Alcalá, di con el árabe mayrà, fidelísima traducción del latín matrice. Fué entonces cuando caí en la cuenta de la formación de un topónimo compuesto por los árabes a base de mayra más el sufijo -it; frente a otro topónimo, compuesto por los mozárabes a base de matrice y del mismo $-i t^{\prime \prime 61}$.

De esta manera existirían dos recintos madrileños -origen, según Oliver, de la expresión Madriles-, uno visigodo y otro musulmán, cada uno de ellos con un nombre propio: “[...] comprendí que Madrit y Mayrit correspondían [...] a un sustrato árabe y mozárabe de la región madrileña, donde los compuestos a base del sufijo -it veía firmemente arraigados" ${ }^{2}$. Ambos topónimos coexistirían durante el dominio islámico de una manera equilibrada hasta que la conquista cristiana inclinó la balanza hacia la forma mozárabe. De esta resultaría la actual forma de Madrid, la cual estaría ya consolidada en la época de redacción del fuero ${ }^{63}$.

La propuesta de un doble origen alcanzó un gran éxito y divulgación, y especialistas de todas las ramas históricas hicieron suyos los postulados de Jaime Oliver. No obstante, no todos dieron por buenas las conclusiones del filólogo zaragozano. De hecho, desde la filología árabe sus propuestas fueron sometidas a un concienzudo análisis crítico. Ello sacó a la luz algunos errores de los planteamientos del autor, especialmente en la evolución del nombre al actual. Joan Coromines ya puso en evidencia las dificultades de hacer relacionar el nombre latino con el actual, ya que, señala, lo más "cómodo" es aceptar la evolución hacia Madrit-Madrid (/matrit/) desde la forma árabe Mayrit (/ majrit/), siendo la forma Maydrit la "documentación de un proceso intermedio -yr- > -ydr- > -dr-" ${ }^{64}$. Sin embargo, reconocía que su estima por las aportaciones de Jaime Oliver le impedía abandonar la posibilidad de una doble denominación. Para ello echó

\footnotetext{
59 "[...] un curso natural de agua que a un cauce artificial; lo mismo significa 'espiradero de agua', 'curso o corriente de agua al aire libre', que 'alcantarilla', 'caño, 'albañar', que 'canal subterráneo"' (OLIver Asín, Historia del nombre "Madrid", pp. 101).

${ }^{60}$ IBIDEM, pp. 232-236.

${ }^{61}$ IBIDEM, p. 238.

62 IBIDEM, p. 239.

63 Aguinaga, "Los madrileños del fuero", p. 8.

${ }^{64}$ Coromines, Topica Hesperica, Vol. 1, pp. 114-116.
} 
mano de esa terminación -it, a la que quitó todo sentido y significado y la consideró como resultado de la metátesis de Matrice que acabó por formar la versión árabe de Mayrit. Según el filólogo catalán, la comunidad musulmana que llegó junto al castillo, no acostumbrada al sonido /matrig/ (Matrice) que usaba la población visigoda autóctona, intercambiaría voluntaria o involuntariamente los fonemas de lugar en el vocablo -metátesis- para acercarlo a una voz conocida /magra/ (mayra), dando lugar a /magrit/ (Mayrit).

Del mismo modo, Federico Corriente consideró acertada la propuesta de Matrice como el primer nombre que recibió el recinto, incluso su significado de arroyo matriz. No obstante, para este autor simplemente acabó por desaparecer y no hay que ver en ese Mayrit ninguna traducción o adaptación por parte de la nueva población. La razón principal para desechar esta idea radicaba en el desconocimiento del latín de gran parte de la población musulmana que llegó a la Península Ibérica:

“[...], no hay razón para afirmar que /matríč(e) se tradujera al árabe, ni que realmente existiera ese supuesto */matrít/, que parece engendrado meramente por un subconsciente deseo de encontrar en todo lo andalusí un próximo origen hispánico, incluso cuando ya lo hay, aunque no tan inmediato, como en este caso" ${ }^{\prime 65}$.

Lo mismo opinaba María Jesús Rubiera, quien argumentaba que la forma Madrid era un "cultismo latino" que procedía del árabe Mayrit, dando como resultado formas como Magerit, Matriy, Matric y Madrid ${ }^{66}$. Se rompía así cualquier vínculo entre la forma latina y la árabe, siendo la forma actual una derivación de la segunda de ellas. El mismo Federico Corriente utilizó las primeras referencias en los textos castellanos para demostrar esa derivación:

“[...] el moderno Madrid es sencillamente resultado castellano de la arabización $>$ magrit $<$, a través de un fenómeno de epéntesis perfectamente reflejado por las primeras grafías cristinas: Magderit, Maydrith, Maydrid, Maiedrid, Mayedrid, Mayadrid, Maiedrit y Mayadrt, que Oliver Asín quiso imaginar como eclécticas de los tipso a) $(>$ magrit $<)$ y b) $(>\text { matrit }<)^{67}$.

El gran problema, no obstante, seguía siendo la terminación -it. La propuesta latina de Jaime Oliver no parecía llegar a convencer a expertos en la materia. Coromines refutó la solución del filólogo aduciendo incongruencias temporales: en el momento en que Muhammad I levantó el castillo no se registra la formación de topónimos a partir de

\footnotetext{
5 Corriente Córdoba, "El nombre de Madrid”, p. 90.

66 Rubiera Mata, "La toponimia árabe de Madrid”, p. 170.

67 Corriente Córdoba, "El nombre de Madrid", p. 89.
} 
la mezcla de árabe y latín. A este rechazo se unió Corriente, quien argumentó la falta de otros ejemplos en los que el árabe usara ese sufijo en la Península, por lo que la propuesta de Jaime Oliver carecía de base ${ }^{68}$. La vinculación con etum, por tanto, parecía desvanecerse y el misterio volvía a surgir. La solución no parecía fácil de resolver ${ }^{69}$.

A medida que iba creciendo el debate en torno a esta cuestión, se dejaba de lado la versión latina. A pesar de ello, lograba mantenerse viva, posiblemente debido a una herencia goticista, bien por nostalgia, bien quizá por no atreverse a desecharla completamente. Ya a finales del siglo pasado era residual el apoyo a la existencia de Matrice. Incluso se dio a conocer que el propio Jaime Oliver valerosamente había admitido más adelante su error y había descartado de manera definitiva la opción bajolatina: “[...] ante el nombre 'Madrid' no hay que hacer cábalas en busca de antecedentes ibéricos, celtas, romanos o visigodos. Madrid, como entidad de población, no es premusulmán [...] o sea que nuestra capital ha comenzado llamándose Mayrit"

Ello implicaba, además, que la apuesta por un origen visigodo de Madrid quedaba en entredicho, mermada de antemano por la inexistencia de hallazgos arqueológicos que diesen indicios sobre un asentamiento estable pre-islámico. Hoy en día, el origen visigodo parece totalmente descartado por la mayoría de especialistas. No obstante, sigue existiendo en la historiografía matritense una cierta tendencia a hacer resurgir esa teoría goticista de manera puntual ${ }^{71}$. A pesar de ello, parece ya definitivamente asentada la teoría del origen islámico tanto del nombre como del asentamiento madrileño.

\subsection{Una nueva propuesta}

Antes de entrar de lleno en materia, quisiera dejar claro que parto de la idea de que el nacimiento de Madrid está vinculado al mundo bereber. El grueso de la población que habitó en el Madrid islámico lo constituyó población de origen norteafricano, incluso es probable que su llegada se produjera antes de la construcción de la fortaleza emiral, considerada como el nacimiento oficial de Madrid. Por ello, considero imprescindible tener en cuenta esa raíz bereber a la hora de abordar el origen etimológico de la Villa madrileña.

\footnotetext{
68 IBIDEM, p. 89, nota 5.

69 "Coromines señala, como posible factor coadyuvante a la metátesis, la inexistencia de la raíz [trg], a la que el árabe atribuiría */matrig/, metanalizándolo como nombre de lugar [...] y admite por el contrario una posible contaminación con el bien conocido /magra/: lo primero es bastante posible, mas no tanto lo segundo, puesto que el árabe hace su análisis morfofonémico sobre el conjunto de la palabra, en busca de una raíz identificable, y no por segmentos. Teniendo en cuenta la fácil alternancia de $/ t / y / d /$ a los que en muchos dialectos antiguos, representados en la documentación andalusí, sólo distinguía la velarización, es más probable que el factor coadyuvante de la metátesis fuese contaminación con la conocida raíz [jrd]" (Corriente Córdoba, "El nombre de Madrid", p. 89, nota 6).

70 Oliver Asín, "Notas sobre el uso del árabe 'Mayrà' "Madrid", p. 225.

71 Manuel Retuerce, por ejemplo, todavía se hacía eco en el año 2000 de la teoría del doble origen del nombre Madrid, siguiendo las teorías de Jaime Oliver y mantenía viva la opción de un asentamiento visigodo (Retuerce Velasco, "El agua en el Madrid andalusí', p. 42). También
} 
A modo de introducción, señalaré que las comunidades bereberes que llegaron a la Península Ibérica tendieron a nombrar sus lugares de asiento con el nombre de su clan o tribu, especialmente en los lugares de nueva fundación. Para ello, fue muy habitual la fórmula Bani + antropónimo ${ }^{72}$, que tantos topónimos ha dejado en la geografía peninsular. Ello es reflejo no sólo de su organización social ${ }^{73}$, sino también de su deseo de identificar su asentamiento con su tribu de origen. Tal fue el caso en el territorio de La Mancha, donde dominaron los nombres tribales en las nuevas localidades ${ }^{74}$. En el territorio al norte de Toledo se asentó la tribu de los al-Famín, los cuales dejaron un reguero de topónimos por la zona, como es el caso de Alamín. No obstante, no solo echaron mano de sus orígenes familiares. La naturaleza y sus diferentes elementos también jugaron en bastantes ocasiones un papel esencial en la formación de topónimos bereberes, al adquirir una presencia especialmente relevante en la vida cotidiana de esas poblaciones: "relieve (orónimos), de la hidrografía (hidrónimos), de la pedología y sobre todo del medio biogeográfico (fitónimos, por ejemplo)"'75. En esa zona al norte de Toledo ocupada por los al-Famín no faltaron ejemplos, como Almorox, procedente de al murug o 'el prado'.

Madrid entra en la Historia oficial como Mayrit. Así es como aparece por primera vez en la documentación y así es como lo debemos entender. Lo hace a través de los textos árabes y con cuatro variantes diferentes: Mayrit, Majrit, Mahrit y Masrit. No obstante, Christine Mazzoli señala que es la primera de ellas la más habitual, mientras que el resto aparece de manera excepcional y en textos bastante tardíos, lo que podría deberse, más que a una verdadera variante, a una simple confusión del copista, dado que las tres

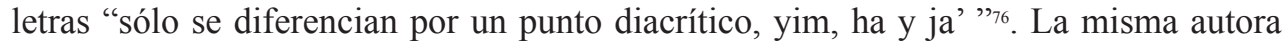
francesa indica en qué textos aparece cada una de estas versiones:

"La forma Mayrit se encuentra en Ibn Hayyan [...], hábil compilador de noticias anteriores a su tiempo, que tomó de la crónica de al-Razi [...] un pasaje relativo a las obras del emir Muhammad I, entre éstas, la edificación de Mayrit [...]. Se conserva la forma Majrit, de manera aislada, en el Kitab Ruyar de al-Idrisi [...]. La edición crítica de la obra fue realizada a partir de los seis manuscritos completos que se conocen, y aparece la forma Majrit en uno de éstos [...]. El oriental Yaqut [...] dedicó una entrada de su diccionario a Mayrit y otra a Mahrit"' ${ }^{\prime 7}$.

\footnotetext{
Guichard, Al-Andalus. Estructura antropológica de una sociedad islámica en Occidente, p. 410. IBIDEM, p. 189.

González González, Repoblación de Castilla la Nueva, Vol. 1, p. 16.

Delort, Introduction aux sciences auxiliaires de l'histoire, p. 184.

Mazzoli-Guintard, Madrid. Pequeña ciudad de al-Andalus, p. 37.

IBIDEM, p. 37.
} 
Nadie duda hoy de que la raíz etimológica de Madrid reside en la palabra mayra. En este sentido, Jaime Oliver acertó de pleno. También encontramos un gran apoyo a la acepción de la palabra elegida por el filólogo: canal subterráneo. El mismo autor volvió a ratificar ese significado en la revisión que a posteriori realizó sobre sus propios estudios, apoyándose en las aportaciones de Reinhart Dozy ${ }^{78}$ :

"Creo haber demostrado que mayra, en su significado principal de 'corriente o conducto de agua', ha tenido en España y en el Norte de Marruecos un desarrollo semántico muy particular, que le ha llevado a convertirse en un término con capacidad para ser usado en el sentido de 'canal artificial', tanto de los que se extienden por encima de huertas como de los subterráneos que forman parte del sistema de algunas ciudades ${ }^{79}$.

Así se ha traducido en infinidad de obras que se han ido publicado con posterioridad, creando de esta manera un consenso que ha ido más allá de lo académico y ha alcanzado al público en general, dentro de los límites de la repercusión actual de la Historia. Libros, revistas, visitas guiadas, etc., todo tipo de medios de difusión al alcance de la población donde se recogen los canales subterráneos que dieron nombre a Madrid. No faltaron entre los apoyos a este significado especialistas del nivel de la arabista María Jesús Rubiera, quien en 1990 dejaba ver su convicción escribiendo que "Mayrit, Magerit, Matriy, Matric y Madrid, son sinónimos: todos hacen referencia a los canales subterráneos que permitieron a Madrid ser fortaleza de los árabes"so.

Sin embargo, a pesar de ese cierto consenso, el significado de Mayrit no es inequívoco. El primero en señalar la posibilidad de otros significados alternativos fue el propio Jaime Oliver, como he comentado antes, al reconocer que dicha palabra equivaldría también a "espiradero de agua, curso o corriente de agua al aire libre" 81 . No obstante, el filólogo no la tuvo en cuenta. Ese doble significado lo volvería a repetir medio siglo más tarde Christine Mazzoli: "magra désigne, outre un canal artificiel, un fil d'eau, un courant d'eau” ¿2. ¿Por qué Oliver Asín eligió la de canal subterráneo? Considero que la realidad que dibuja la documentación tanto escrita como arqueológica para aquella medina madrileña entra en contradicción con la propuesta del filólogo. Creo que el error viene a raíz de que sus valiosísimas aportaciones filológicas no fueron acompañadas de un concienzudo análisis de la documentación y de la propia historia de la villa. La contradicción más importante es el hecho de que, como he defendido en otros trabajos ${ }^{83}$,

\footnotetext{
IBIDEM, p. 44.

9 Oliver Asín, "Notas sobre el uso del árabe "Mayrà' "Madrid", p. 228.

80 Rubiera Mata, "La toponimia árabe de Madrid”, p. 170.

1 Oliver Asín, Historia del nombre "Madrid”, pp. 101.

2 Mazzoli-Guintard, Madrid. Petite ville de l'Islam médiéval, p. 41.

83 JimÉnEz RAYADO, Eduardo, El agua en el origen y desarrollo de Madrid en la Edad Media, pp. 257-271; Agua y sociedad en Madrid durante la Edad Media, pp. 163-188 (tesis en proceso de publicación).
} 
esa red subterránea de canales no existió como tal durante el periodo islámico ${ }^{84}$. Ni la arqueología ${ }^{85}$ ni la documentación escrita han dado indicio alguno sobre la presencia de esas canalizaciones subterráneas. Tampoco la realidad natural donde se asentó Mayrit, rodeada de grandes cantidades de manantiales y acuíferos, parece ayudar a ratificar la teoría de los qanats. Entonces, ¿cómo explicar que la primera comunidad madrileña impuso el nombre empleando la palabra mayra? ¿Qué ocurre una vez más con el famoso sufijo -it? Creo que la Historia social y, sobre todo, la Historia ecológica pueden ofrecer una perspectiva nueva para abordar ambas cuestiones y hallar una respuesta satisfactoria. Ante todo, he de subrayar que parto de las propuestas de otros autores que previamente ya pusieron en duda el significado dado por Oliver Asín. Décadas más tarde de su famosa obra, Federico Corriente ponía sobre la mesa la cuestión del significado de mayra $\mathrm{y}$, partidario de cuestionar la existencia de esa red ante la falta de documentación, se mostraba partidario de la otra acepción:

“/magra/ significa meramente "cauce" no tiene por qué implicar conducción subterránea de aguas (aunque contemporáneamente haya acabado significando "alcantarilla") siendo así que para el étimo de Madrid todos aceptamos como punto de partida un "arroyo" en superficie, ni de manera más amplia creemos que haya en toda la problemática de este étimo ninguna relación con dichos viajes, cuya datación para nada puede apoyarse en esta etimología"86.

Como he señalado, también Christine Mazzoli sacó a relucir ese doble significado, y, aunque con mayor cautela que Corriente, daba a entender la posibilidad de que, bajo aquel nombre, la comunidad originaria madrileña hiciera alusión a la gran cantidad de cursos fluviales que se encontró en sus alrededores.

Mi objetivo aquí es dar solidez a esta segunda posibilidad. Para ello, como he señalado, considero imprescindible echar mano de la Historia ecológica. La reconstrucción del entorno natural resulta imprescindible para completar el conocimiento sobre la sociedad histórica que se desenvolvió en él: entender cómo concibió dicha sociedad el área que ocupó podría arrojar mucha luz sobre la formación de topónimos. Con una perspectiva ecológica, la documentación permite recrear de una manera aproximada las condiciones naturales donde se desarrolló la primera comunidad madrileña. A partir de los textos disponibles y del legado arqueológico, parece evidente que dichas condiciones eran óptimas para el desarrollo humano, especialmente en lo referente a la oferta hídrica. El área donde se asentó esa población madrileña se encontraba junto a tres arroyos

\footnotetext{
4 Los primeros canales subterráneos comenzaron a construirse en los albores del siglo XVII.

85 La canalización hallada en la Plaza de los Carros dista mucho de poder ser considerada de manera categórica como qanat: JimÉnEz RAYADo, Eduardo, El agua en el origen y desarrollo de Madrid en la Edad Media, pp. 99-100; "El abastecimiento de agua en Madrid durante la Edad Media”, pp. 256-257; Agua y sociedad en Madrid durante la Edad Media, pp. 169-171 (tesis inédita).

86 Corriente Córdoba, "El nombre de Madrid", p. 89.
} 
que corrían en paralelo: dos al norte, llamados posteriormente Arenal o de San Ginés y Leganitos, y uno al sur, llamado más tarde de San Pedro. En torno a este surgió la primera comunidad. Algo más alejado recorría, de norte a sur un pequeño río al que llamaron Guadarrama (hoy Manzanares), y por el este nuevos arroyos enriquecían el solar madrileño: Atocha y Abroñigal, entre otros. A ello se sumaba una gran cantidad de manantiales naturales a los que se añadirían los primeros manaderos abiertos por mano humana. Por último, una gran bolsa de agua se hallaban bajo el suelo, a poca profundidad y fácilmente accesible desde la superficie. Con esa oferta hídrica, el área madrileña destacaría en medio del paisaje seco característico de La Mancha ${ }^{87}$. Quizá esta especie de isla en medio del desierto revestiría al agua de un valor más excepcional de lo habitual, y la convertiría en la característica principal del lugar y, en consecuencia, una herramienta fácil para nombrar ese espacio. La población, al ver la cantidad de agua superficial de la zona, echaría mano de la palabra mayra para identificarla. No se esperarían para ello a construir los supuestos canales artificiales bajo tierra. El error del Oliver Asín fue no poner en valor la realidad natural, lo que le llevó a elegir la otra acepción de la palabra.

Lo que sigue sin solucionarse es la cuestión de la terminación -it. ¿Es posible pensar en una metátesis de la palabra original, como indicaba Coromines? Es una opción, pues nuestro diccionario está lleno de palabras surgidas por un error a la hora de situar los sonidos y bien podría haber ocurrido igualmente con esa mayra convertida así en Mayrit. Sin embargo, considero necesario barajar otras posibilidades que reabran una vez más un debate que pueda aportar nuevos avances al respecto. Porque creo que a la hora de elaborar su hipótesis, Oliver Asín tampoco tuvo en cuenta otra característica de la realidad madrileña medieval: su fuerte componente bereber. En este sentido, Christine Mazzoli, en su estudio sobre el Madrid islámico, se preguntaba dónde está en todas estas hipótesis etimológicas, esa comunidad bereber ${ }^{88}$ ¿Qué papel tuvo en la elaboración del nombre? Descartada la opción latina, ¿fue ella o quienes llegaron con la fundación de la fortaleza los responsables de significar la zona? Para ello, creo imprescindible tener en cuenta la naturaleza de la comunidad que dio origen al asentamiento y que muy probablemente fuera la responsable de aportarle un nombre y, con él, un significado.

En el momento de su nacimiento, el centro de la Península estaba dominado por el clan de los Banu Salim, y bajo este dominio fueron habitando el territorio diferentes grupos pertenecientes a la tribu bereber Masmuda. Es dentro de esta comunidad norteafricana en la que hay que situar las raíces madrileñas. Por ello, para su mayor comprensión habrá que acercarse a las características que impusieron sobre el territorio peninsular $\mathrm{y}$, para nuestro caso, especialmente en materia lingüística, en busca de algún posible indicio sobre la razón de existencia de dicha terminación.

Las comunidades bereberes trajeron a la Península Ibérica el árabe que había sido impuesto en el norte de África desde su islamización. Sin embargo, la arabización no fue

\footnotetext{
87 González GonzÁlez, Repoblación de Castilla la Nueva, Vol. 1, p. 9.

88 Mazzoli-Guintard, Madrid. Pequeña ciudad de al-Andalus, p. 46.
} 
perfecta, una vez que estas poblaciones mantuvieron de una manera más o menos clara algunos aspectos de sus lenguas originales, que en muchas ocasiones sacaban a la luz ${ }^{89}$. Lo mismo ocurrió con otros grupos islamizados, lo que hizo del árabe de al Andalus más un conjunto de dialectos que una lengua homogénea ${ }^{90}$. La escasa presencia de población árabe en muchos territorios de la Península hizo más fácil la pervivencia de elementos lingüísticos pre-islámicos y acentuó esa diversidad bajo la capa del árabe oficial ${ }^{91}$. Esta mezcla lingüística presente en las poblaciones bereberes peninsulares quedó reflejado en muchos de los topónimos que fueron estableciendo en su territorio. Bajo esa capa arabizada, en muchos de ellos se puede intuir la huella de sus lenguas de origen ${ }^{92}$. Teniendo en cuenta esto, se hace inevitable pensar en la presencia de elementos bereberes en el nombre Mayrit. Christine Mazzoli se preguntaba si la forma original bereber fue borrada tras la instalación de la fortaleza y la llegada de autoridades árabes ${ }^{93}$. ¿Se borró completamente aquella huella? Una posibilidad es que los historiadores y geógrafos andalusíes confundieran el nombre original, dado su escaso conocimiento de las lenguas norteafricanas ${ }^{94}$, y lo adaptaran al árabe usando una palabra por ellos conocida, mayra, dándole así un sentido. Pero quizá esa huella bereber no esté tan oculta, y quizá esté ahí la respuesta al enigmático -it.

Volviendo a lo comentado en la introducción a este capítulo, por norma general el grupo bereber fundador de una ciudad utilizaba el nombre de su tribu para bautizarla, lo que indicaría que su asentamiento se realizó en atención a sus vínculos tribales ${ }^{95}$. No obstante, hay que asumir esta práctica con precaución y no considerarla como una norma única ${ }^{96}$. De hecho, esta práctica solía darse en los casos en que se tratase de una tribu o familia poderosa $^{97}$. Menos frecuente, aunque no por ello inexistente, fue el uso de elementos naturales. En el capítulo sobre los hidrónimos ya he hecho una pequeña introducción a la toponimia bereber, y se ha podido ver la propuesta de Jaime Oliver, sobre palabra tit. También he hecho alusión a la labor de Helena de Felipe. Es hora de sacar a relucir lo que la autora podría aportar a la reconstrucción del topónimo madrileño. En su extenso trabajo sobre la identidad bereber en el territorio andalusí, realizaba un estudio sobre la onomástica procedente del norte de África y entre las diferentes fórmulas hablaba de

\footnotetext{
89 Mohamed Meouak señalaba la frecuencia con que las poblaciones del Magreb utilizaban su lengua materna, bereber, en sus expresiones literarias, incluso religiosas durante la Edad Media: "Pour cette dernière langue [bereber], il existe des exemples curieux pris dans la littérature et dans lesquels on voit se manifester un désir d'expression dans la langue maternelle (berbère), voire même une profonde volonté d'enseigner les principes fondamentaux de l'Islam" (Meouak, "Langue arabe et langue berbère dans le Maghreb médiéval: notes de philologie et d'histoire", p. 7).

90 Asín Palacios, Contribución a la toponimia árabe en España, p. 14.

91 Guichard, Al-Andalus. Estructura antropológica de una sociedad islámica en Occidente, p. 477.

92 Oliver Asín, En torno a los orígenes de Castilla, p. 28.

93 Mazzoli-Guintard, Madrid. Pequeña ciudad de al-Andalus, p. 46.

94 Felipe Rodríguez, Identidad y onomástica de los beréberes de al-Andalus, p. 78.

5 Felipe Rodríguez, Identidad y onomástica de los beréberes de al-Andalus, p. 68.

IBIDEM, pp. 62 y 68.

Asín Palacios, Contribución a la toponimia árabe en España, p. 10.
} 
lo habitual que era el uso del femenino o de diminutivos como Tayit ${ }^{98}$. En este sentido coincide con un apunte que leí en un trabajo realizado medio siglo antes por Miguel Asín. En él señalaba también el uso en territorio peninsular de ese sufijo como sinónimo de diminutivo, utilizando como ejemplo la ciudad de Benasayt. Según el propio autor, de ese sufijo procederían los diminutivos en español y catalán "-ito/ita" y "-et" dejando así ver una influencia mayor del mundo bereber de lo que podríamos pensar.

De nuevo, surge la tentación de relacionar ese diminutivo bereber con el problemático -it. No resulta descabellado pensar en una fusión de la lengua norteafricana con el árabe para crear el topónimo. Como hemos visto, no sería la primera vez que sucede tal fusión. De ser acertada esta hipótesis, Mayrit cambiaría su significado de "abundantes cauces" por el de "pequeño/s cauce/s". Ninguno de los dos casos chocaría con las características del territorio que querían nombrar. Por un lado, se trataba de un paisaje donde, efectivamente, corría una gran cantidad de cauces fluviales superficiales, como los arroyos San Pedro, Arenal, Leganitos, Atocha, o el río Manzanares. Por otro, ninguno de estos cauces mostraba un gran caudal, por lo que se entiende que sus habitantes quisieran significar la escasa cantidad de agua a la hora de nombrar la zona. O quizá solo se referirían a uno. En este caso, casi todas las apuestas apuntarían al arroyo conocido como San Pedro, el cual circulaba entre las dos colinas sobre las que se asentó Mayrit y cuyas aguas sirvieron de principal sustento para gran parte de su población. Se podría pensar en una alternativa: el Manzanares, con su sempiterna fama de río de bajo caudal. Ello significaría una relación más estrecha de lo que aparentemente hubo entre este y el asentamiento. Demasiado lejano y sin atravesar la ciudad, el futuro Manzanares tan solo le serviría para abastecerse de pescado, de agua para posibles huertas y, quizá, para momentos de ocio y de relajación. A pesar de ello, ¿podría Mayrit hacer referencia al río? Son meras suposiciones que, probablemente, nunca podremos saber.

Lo que parece claro es que el nombre de Madrid, factor primordial de identificación de una comunidad, se forjó a partir del agua. Pero no un agua encauzada por la mano humana, sino aquella que corría por la superficie del solar en el que un primer grupo bereber se asentó y que daría origen a lo que es hoy capital de España. Ese nacimiento conllevó una vinculación especial entre aquella y la localidad. No tenerla en cuenta supondrá no llegar a entender nunca la identidad madrileña: quienes la nombraron quisieron resaltar esa especial relación con el agua y, dejar bien claro, su importancia en su origen y desarrollo:

"[...] el lugar significado [...] es reconocido por los individuos: su nombre, pues, es un documento que atestigua las relaciones entre el ser humano y el medio ambiente; la forma de ese nombre evoca la lengua hablada por los que la eligieron y, a menudo, la intención o los motivos de su opción"100.

\footnotetext{
98 Felipe Rodríguez, Identidad y onomástica de los beréberes de al-Andalus, p. 40.

99 Asín Palacios, Contribución a la toponimia árabe en España, p. 58

100 Delort, Introduction aux sciences auxiliaires de l'histoire, p. 184; cit. Mazzoli-Guintard, Madrid. Pequeña ciudad de al-Andalus, p. 44.
} 


\section{Bibliografía citada}

Aguinaga, Enrique de, "Los madrileños del fuero", Ciclos de conferencias: El fuero de Madrid de 1202, 8 (2003), 32 p.

Arroyo ILERA, Fernando, Agua, paisaje y sociedad en el siglo XVI: según las Relaciones Topográficas de Felipe II, Ed. Umbral, Madrid, 1998.

Asín Palacios, Miguel, Contribución a la toponimia árabe en España, Gráficas Versal, Madrid-Granada, 1944.

Ballester, Xaverio, “Toponimia Valenciana Prejaimina”, Lıburna, 8 (2015), pp. 51-78.

BAuman, Zygmunt, Identidad, Editorial Losada, Buenos Aires, 2007.

Coromines, Joan, Estudis de toponímia catalana (2 vol.), Ed. Barcino, Barcelona, 1965 y 1970.

Coromines, Joan, Topica Hesperica, 2 Vols., Ed. Gredos, Madrid, 1972.

Corriente Córdoba, Federico, "El nombre de Madrid", Madrid del siglo IX al XI, Dirección General de Patrimonio Cultural, Madrid, 1990, pp. 87-91.

Covarrubias, Sebastián de, Tesoro de la lengua castellana o española, Imprenta del Reyno, Madrid, 1611.

Curchin, Leonard, "Los topónimos de la Galicia romana: nuevo estudio", Cuadernos de estudios gallegos, LV N. ${ }^{\circ}$ 121, (2008), pp. 109-136.

Del Val Valdivieso, María Isabel, "La identidad urbana al final de la Edad Media", AMEA. Anales de Historia Medieval de la Europa Atlántica, 1 (2006), pp. 5-28.

Delort, Robert, Introduction aux sciences auxiliaires de l'histoire, Armand Colin, París, 1969.

Dikr bilad al-Andalus, ed. Luis Molina, Instituto 'Miguel Asín', Madrid, 1983, vol. 2. Felipe Rodríguez, Helena de, Identidad y onomástica de los beréberes de al-Andalus, Editorial CSIC, Madrid, 1997.

García de CortÁzar, José Ángel, "Espacio y hombre en la España norteña en la Edad Media", Anales de la Universidad de Alicante: Historia medieval, 6 (1987), pp. 49-74.

GonzÁlez GonzÁlez, Julio, Repoblación de Castilla la Nueva, 2 Vols., Universidad Complutense, Madrid, 1975.

Guerrero Navarrete, Yolanda, "La fiscalidad como espacio privilegiado de construcción político identitaria urbana: Burgos en la Baja Edad Media”, Studia historica. Historia medieval, 30 (2012), pp. 43-66.

Guichard, Pierre, Al-Andalus. Estructura antropológica de una sociedad islámica en Occidente, Seix Barral, Barcelona, 1976.

JARA Fuente, José Antonio, "Sobre el Concejo cerrado. Asamblearismo y participación política en las ciudades castellanas de la Baja Edad Media", Studia Historica. Historia Medieval, 17 (1999), pp. 113-136. 
JimÉnEZ GADEA, Javier, "Los asentamientos beréberes en al-Andalus", V Semana de Estudios Medievales, Nájera del 1 al 5 de agosto de 1994, José Ignacio de la Iglesia Duarte (coord.), Instituto de Estudios Riojanos, Logroño, 1995, pp. 209-215.

JimÉnEZ RAYAdo, Eduardo, El agua en el origen y desarrollo de Madrid en la Edad Media, Al-Mudayna, Madrid, 2011.

JIMÉNEZ RAYADO, Eduardo, "El abastecimiento de agua en Madrid durante la Edad Media", Agua y sociedad en la Edad Media hispana, María Isabel del Val Valdivieso (coord.) y Juan Antonio Bonachía Hernando (coord.), Universidad de Granada, Granada, 2012, pp. 241-273.

JimÉnez RAYAdo, Eduardo, Agua y sociedad en Madrid durante la Edad Media, Universidad de Valladolid, 2016 (Tesis doctoral).

Lorenzo Arribas, José Miguel, "Mantua Carpetana", Gran Enciclopedia Cervantina, Vol. VII (2011), pp. 7537-7539.

MaÑas NúÑEz, Manuel, “Sobre los hidrónimos Marco y Marimarco de Cáceres”, Anuario de Estudios Filológicos, vol. XXXIX (2016), pp. 343-347.

Martín Gutiérrez, Emilio, “Análisis de la toponimia y aplicación al estudio del poblamiento. El alfoz de Jerez de la Frontera durante la Edad Media", Historia. Instituciones. Documentos, 30 (2003), pp. 257-300.

Martino Redondo, Eutimio, "Base científica de la nueva aproximación a la toponimia. El calco hidronímico y la toponimia antigua, en, Antigüedad y cristianismo". Antigüedad y cristianismo. Monografías históricas sobre la Antigüedad tardía, XXX (2013), pp. 233-246.

Mazzoli-Guintard, Christine, Madrid. Petite ville de l'Islam médiéval (IX-XXI siècles), Presses Universitaires de Rennes, Rennes, 2009.

Mazzoli-Guintard, Christine, Madrid. Pequeña ciudad de al-Andalus (siglos IX-XXI), Al-Mudayna, Madrid, 2011.

MenÉndez PidAl, Ramón, "La etimología de Madrid y la antigua Carpetania", Revista de la Biblioteca, Archivo y Museo del Ayuntamiento de Madrid, 51 (1945), 3-24.

Meouak, "Langue arabe et langue berbère dans le Maghreb médiéval: notes de philologie et d'histoire", Al-Andalus Magreb: Estudios árabes e islámicos, 13 (2006), 329-335.

Moreu-Rey, Enric, Els nostres noms de lloc, Ed. Moll, Palma de Mallorca, 1982.

Muñoz FERnÁndez, Ángela, "Metáforas del agua en la cultura urbana madrileña (ss. XIII-XVIII)", Historia del Abastecimiento y usos de agua en la Villa de Madrid, F. J. Martínez del Olmo (coord.), Conferencia Hidrográfica del Tajo y Canal de Isabel II, Madrid, 2000, 163-182.

Oliver Asín, Jaime, Historia del nombre “Madrid”, Instituto Miguel Asín, Madrid, 1959. Oliver Asín, Jaime, En torno a los orígenes de Castilla. Su toponimia en relación con los árabes y los beréberes, Real Academia de la Historia, Madrid, 1974. 
Oliver Asín, Jaime, "Notas sobre el uso del árabe 'Mayrà' "Madrid"”, Conferencias y apuntes inéditos, Agencia Española de Cooperación Internacional. Ediciones de Cultura Hispánica, Madrid, 1996, pp. 219-228.

Pedrero Sancho, Rosa María, "El hidrónimo prerromano Mira", Emerita: Revista de lingüistica y filología clásica, Vol. 64, 2 (1996), pp. 361-274.

Quintana, Jerónimo de la, Historia de la antigüedad, nobleza y grandeza de la Villa de Madrid, Imprenta del Reyno, Madrid, 1628.

Relaciones topográficas mandadas hacer por Felipe II. Madrid, ed. Alfredo Alvar Ezquerra, CSIC, Madrid, 1993.

Retuerce Velasco, Manuel, "El agua en el Madrid andalusí", Historia del Abastecimiento y usos de agua en la Villa de Madrid, F. J. Martínez del Olmo (coord.), Conferencia Hidrográfica del Tajo y Canal de Isabel II, Madrid, 2000, pp. 37-54.

Rubiera Mata, María Jesús, "La toponimia árabe de Madrid", Madrid del siglo IX al XI, Dirección General de Patrimonio Cultural, Madrid, 1990, pp. 165-170.

Ruiz de Loizaga, Saturnino, "Toponimia mayor y menor del Occidente de Álava en la Alta Edad Media”, Sancho el sabio: Revista de cultura e investigación vasca, 4 (1994), pp. $247-284$

Ruzz Gómez, Francisco, "La ilusión de la identidad en el imaginario medieval según Las Partidas", Edad Media. Revista de Historia, 9 (2008), pp. 239-261.

Sanz García, José María, "Madrid. Mitos y utopía”, Anales de Geografia de la Universidad Complutense, n. extra 1 (2002), pp. 33-126.

SolóRzano TelecheA, Jesús Ángel, "La identidad urbana y la Historia social de la política en el mundo urbano español y portugués en la Baja Edad Media", Studia historica. Historia medieval, 33 (2015), pp. 327-341.

TORT i Donada, Joan, "Toponimia y marginalidad geográfica. Los nombres de lugar como reflejo de una interpretación del espacio", Scripta Nova: Revista electrónica de geografia y ciencias sociales, 7 (2003), pp. 133-156. 